\title{
COVID-19 Could Leverage a Sustainable Built Environment
}

\author{
Manuel Duarte Pinheiro *(D) and Nuno Cardoso Luís \\ Técnico, Universidade de Lisboa, CERIS, Av. Rovisco Pais, N 1, 1049-001 Lisboa, Portugal; \\ nunoluis@tecnico.ulisboa.pt \\ * Correspondence: manuel.pinheiro@tecnico.ulisboa.pt; Tel.: +351-93465841
}

Received: 24 June 2020; Accepted: 19 July 2020; Published: 21 July 2020

\begin{abstract}
The health system's response to the COVID-19 pandemic has involved research into diagnoses and vaccines, but primarily it has required specific treatments, facilities and equipment, together with the control of individual behaviour and a period of collective confinement. The aim of this particular research, therefore, is to discover whether COVID-19 is capable of changing the built environment (BE) and leveraging specific solutions for sustainable buildings or urban areas. Some historical reviews of infectious pandemics have highlighted the development of new solutions in the $\mathrm{BE}$ as an additional contribution towards preventing the spread of infection. The BE has an important role to play in supporting public health measures and reducing the risk of infections. The review of potential COVID-19 measures shows the existence of well-referenced solutions, ranging from incremental alterations (organisation of spaces, erection of physical barriers) to structural alterations (windows, balconies) with different timeframes and scales (ranging from changes in building materials to the design of urban areas). A critical exploratory assessment makes it possible to identify measures that may help not only to reduce the risk of COVID-19 transmission (or even prevent it), but also to increase resilience, improve air quality and lower energy requirements or the use of materials, and thus potentially increase the sustainability of the BE. COVID-19 measures challenge us to rethink buildings and urban areas and potentially leverage sustainable BE solutions with win-win outcomes (minimalist design and other solutions). The specific composition of this set of measures must, however, be further researched.
\end{abstract}

Keywords: COVID-19; infection risks; built environment; buildings; urban areas; resilience; sustainability

\section{Introduction}

Contagious diseases can have disturbing effects on human populations and seriously disrupt their activities [1]. COVID-19 is an infectious disease caused by a new strain of the coronavirus family, SARS-CoV-2 [2]. It belongs to the same family as SARS-CoV-1, which was responsible for the severe acute respiratory syndrome (SARS ) pandemic in 2003 [3].

Since the beginning of 2020, this particular coronavirus has spread at an alarming rate all over the world [2]. According to data provided by the World Health Organisation (2020), the virus has already affected 213 countries, with more than 14 million cases recorded worldwide and more than 600,000 deaths [4].

Besides its effects on public health, the COVID-19 pandemic has had other significant consequences, resulting not only in a series of economic impacts [5] - seriously reducing economic activity, with a 3.0\% recession currently being expected — but also impacts of a social [6] and even physiological nature [7].

The current positive effects on the environment, e.g., the reductions in energy consumption, greenhouse gas emissions and pollution [8], are due to the temporary limitations that have been imposed on activities. The need for extra protective measures may, however, lead to the creation of another 
specific form of solid waste, such as discarded masks and gloves [9]. The reduced capacity of services (e.g., fewer users of schools, restaurants or shops) has increased the consumption of energy, water and cleaning products per service unit. Furthermore, if business returns to its normal levels, the environmental pressures will increase since these have not yet been decoupled from economic activity [10].

Major infectious diseases are critical events [11], and the risk and effects of such maladies present enormous challenges to society and organisations, challenging them to introduce temporary or even more long-term changes. The pandemic dimension of this virus further exacerbates the risks to society (or the perception of them) and highlights the importance of preparedness [12] in meeting the challenges of potential impacts and in taking the correct actions.

Globalisation has brought huge increases in the movements of people and goods, the speed with which ideas can be disseminated and also the potential for the transmission of infectious diseases. Nowadays, there are more people living in urban areas than in rural areas [13]. Urbanisation alters the consequences of infectious diseases [14] and cities create conditions for the growth and spread of new microorganisms. The population has become concentrated in smaller areas, in some cases with poor sanitary conditions, where technology and alterations to the built environment make it possible to mitigate risks [15].

On Web of Science (WoS), there has been a growth in the number of publications this year about COVID-19 (more than 6000 references), but fewer than 1\% of these refer to the built environment or buildings [16]. On ScienceDirect, it is possible to find more than 8000 references, but, again, fewer than $1 \%$ of these are related to the built environment in any way [17].

In more specific research, it is possible to find some articles published in various journals that discuss built environments in relation to the COVID-19 pandemic [18,19], examine potential preventive measures [20] or mainly relate this question to the problem of sustainable development [21].

As far as scientific studies on COVID-19 are concerned, it is worth stating that there is a full range of information; however, these studies focus mainly on the areas of medicine, the pharmaceutical industry, public health and related fields. There are few publications in the scientific literature relating COVID-19 to the built environment and buildings.

The search for solutions that can control the transmission of the effects of diseases like SARS-CoV-2 (COVID-19) has been undertaken mainly within the health system, engaging society in different behavioural actions (such as hygienic measures or social distancing).

When the proposed solutions to infections like COVID-19 and the research conducted into public health are taken beyond the sectoral silos of the health system and behavioural controls, it can be seen that the built environment (buildings and urban areas) can also make a valuable contribution that must be researched and analysed [22].

In the past, certain infections, such as cholera, have influenced and changed the built environment, with the development of new urban areas and infrastructures [23,24]. For some authors [25], infectious diseases and extreme events resulting from climate change are warnings from the planet that the limits may have been reached and that, consequently, a more structural approach to change should be adopted, one that combines environmental concerns with the search for sustainability. Understanding these risks and vulnerabilities provides an opportunity for identifying the changes that need to be introduced. This coronavirus-induced pause represents "a big chance!" for developing more sustainable systems [26]. For Cohen (2020), "one way to offset some of the unfortunate suffering and disruption caused by this event" is by contributing to "a sustainable consumption transition" [27].

The potential for contamination by the COVID-19 pandemic and other fresh outbreaks of the virus calls for a more holistic approach, with more structural changes being introduced into the built environment [14]. The built environment is of major importance within the context of the wider social and economic environment (being responsible for more than $40 \%$ of energy consumption). Furthermore, cities and other urban areas are not only a problem, but they also offer a solution for providing a more sustainable form of development and increasing the potential for infectious disease control. 
The lockdown of urban areas due to the COVID-19 crisis has shown the limits and deficiencies of buildings and other dimensions of the built environment. The essential question is whether these lessons will be learned and whether the changes will result in a move towards lower risks in urban areas and the creation of a more sustainable environment [28].

\section{Research Methodology}

The question posed by this research study is "Could COVID-19 measures leverage a sustainable built environment?" Our paper seeks to identify whether COVID-19 will bring changes to the built environment and whether these changes will or will not promote sustainable solutions in buildings and urban areas.

For this purpose, the methodology (Figure 1) used in this exploratory research begins by reviewing the historical cases of previous pandemic infectious diseases, identifying the changes that these brought to the built environment (Section 3) and analysing examples of such infections and changes.

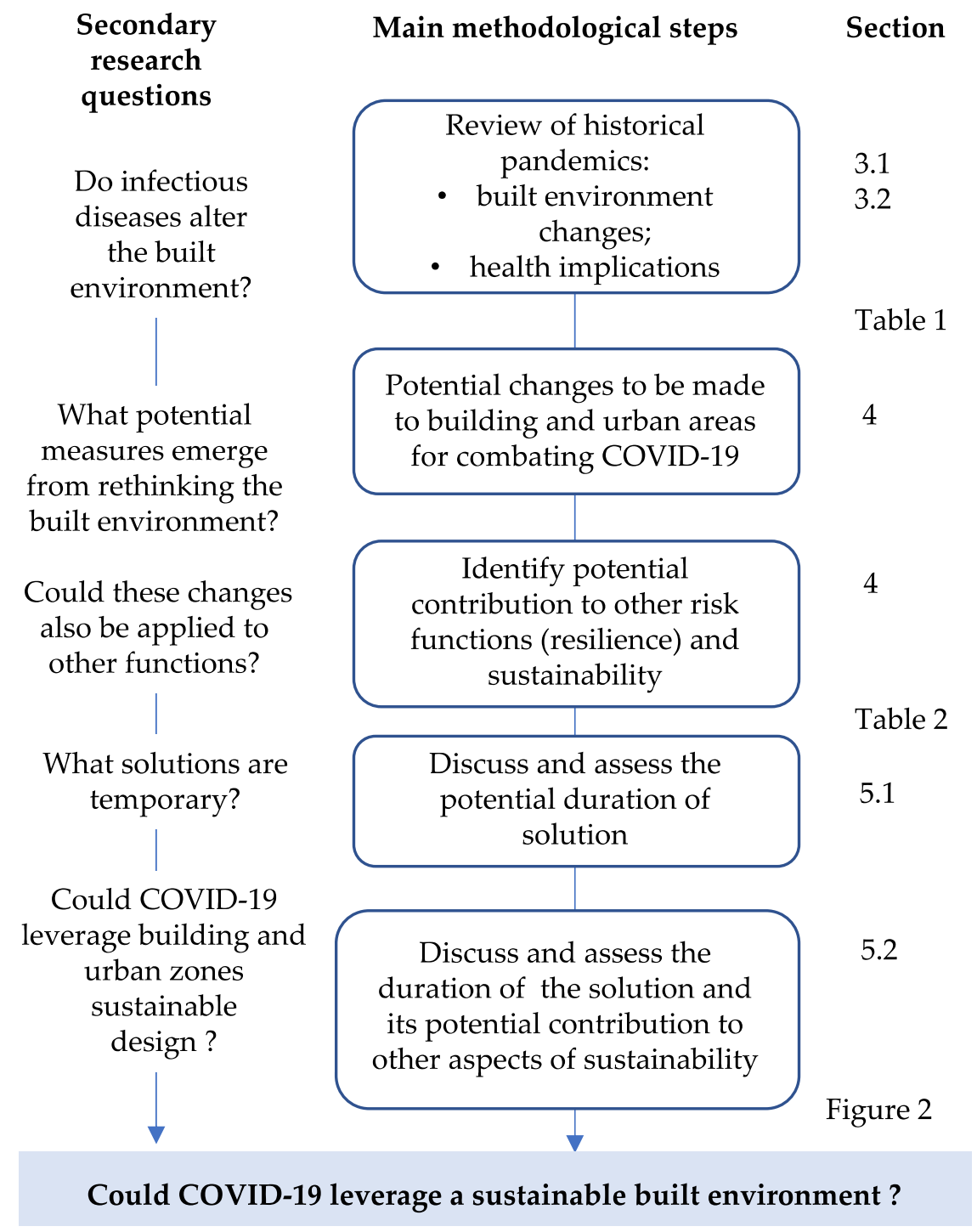

Figure 1. Main methodological steps.

After this, an analysis is made of the strategies and measures that could potentially be adopted to combat the COVID-19 virus (Section 4), seeking to identify the benefits in terms of fighting COVID-19, understanding whether there are also benefits to be obtained for controlling other risks 
(resilience against COVID-19 and other vulnerabilities), and identifying potential contributions towards sustainability (better comfort, lower energy consumption, water and material emissions and better amenities or other socioeconomic conditions).

There then follows a discussion and an assessment as to whether the changes will be temporary (Section 5.1) and whether they will lead to a more sustainable built environment (Section 5.2).

The following aspects are considered in this assessment: (1) which solutions can best respond to the need to reduce COVID-19 risks? (2) what will be the timeframe of the measures and what degree of risk reduction will they guarantee in the fight against COVID-19? and (3) what other benefits will these measures bring in terms of resilience and other aspects of sustainability? For this analysis, three scales were defined:

- The duration (or the need for renewal) of the solution to ensure that it continues to function as a form of risk reduction, with the following time limits being stipulated: 1 day or less, 1 month or less, 1 year or less, 5 years or less, 10 years or less or 25 years.

- The level of benefit of potential solutions for COVID-19 risk reduction is defined on a scale from 0 to 5 , where 0 means solutions that make no contribution; 1 corresponds to solutions that conform to public health conditions; 2 means solutions that reduce the risk of transmission; 3 means solutions that prevent transmission between people; 4 means solutions that prevent inter-community transmission; and 5 means solutions that provide ways of treating the virus.

- A scale from 0 to 10 was also defined to assess the contribution of the solution for COVID-19 to other aspects of sustainability, where 1 means that the solution brings only benefits in the fight against COVID-19 and 10 means that (in addition to having benefits for fighting COVID-19) the solution is also a potential solution with very positive impacts in terms of sustainability.

These criteria were used to identify measures leading to a win-win situation of SARS-CoV-2 (COVID-19) risk reduction and sustainability. In the conclusions (Section 6), the answer to the questions raised by the paper highlights the importance of a potential rethink regarding buildings and urban areas and further research opportunities.

\section{Can Infectious Disease Bring Alterations to the Built Environment?}

\subsection{Diseases and Alterations to the Built Environment}

During the Roman Empire, the appearance of gastrointestinal problems and fevers associated with infectious diseases such as dysentery or typhoid, which spread rapidly among the legions or in the military camps, led to the introduction of hygiene measures. Moving camps for sanitation purposes to preferable sites next to rivers, using isolated tents for injured soldiers (or those displaying symptoms of infectious diseases) and sanitation (complex drainage systems) [29] were just some of the measures implemented at the time.

In the second century, Roman cities had aqueducts and water supply systems ensuring the distribution of safe drinking water. The busiest cities had public bathing facilities, as a way of encouraging hygiene habits, and sophisticated sanitation systems were developed [30]. The concern with public health and the control of infectious diseases was also addressed in the Roman Empire (27 BC-476 AD) through solutions incorporated into the built environment.

The plague, known as the Black Death or the Bubonic Plague, was responsible for several outbreaks that devastated Europe in the mid-fourteenth century, causing the death of millions of people [14]. The horror of that situation has been most expressively captured in non-scientific literature, highlighting the drama and the human strength that was required to overcome the challenges that the plague presented [31]. The disease was caused by a bacterium, Yersinia pestis, which was mainly transmitted through fleas carried by rats and other infected animals. The main form of contagion at the time was via trade routes [32].

Several measures were implemented in an attempt to contain the plague, such as quarantine or restrictions on movement [33] and the closure of ports [34]. Other more specific measures were 
implemented, such as closing public baths and advising people to avoid contact with animals (possible carriers of the disease) [33].

Lilley (2015) says that, after the peak of the plague in 1350, English cities began to be planned in a different and more careful way [35]. Cities were "cleared of dirty and cramped quarters" and more organised public spaces were designed. Architects and other experts began to be employed to help with the planning of cities [35]. The Black Death led to the introduction of major changes in the planning of European cities.

Inspired by the outbreaks of the plague that hit Italy, Leonardo Da Vinci imagined a modern city. The inefficiency of medieval streets was one of the main reasons why the plague spread so quickly. Leonardo made a series of drawings in which he expounded his ideas of an ideal city with modern sanitary facilities and areas designed for the circulation of horses and wagons [36]. His thoughts were too bold and did not leave the paper.

Cholera arrived in Europe in the early nineteenth century via the routes used by traders and travellers from the Middle East. It was responsible for six outbreaks that caused the death of millions of people between the nineteenth and twentieth century, making it one of the worst pandemics in history [37,38]. Quarantine measures were implemented for individuals and for cargo arriving at ports [37].

The miasma theory that was prevalent at the time stated that disease was transmitted through the air [39]. Among the supporters of this theory was Frederick Law Olmsted, a landscape architect and the designer of Central Park in New York. Olmsted believed that open green spaces in the middle of the cities injected fresh air into the environment and had positive effects in curing some diseases. At that time, investments were made in the construction of large parks in the middle of the cities [40].

It was only in 1848 that the British physician John Snow discovered that the disease was transmitted via the faecal-oral route, demonstrating that cholera was spread by water contaminated with human faeces $[37,39]$. Snow mapped cases of the disease in a London neighbourhood (Soho, London) and discovered a link between the infected people and a local water pump with a broken sewer pipe, dumping human waste into the drinking water consumed by those people [41].

After a cholera pandemic that hit France in 1848, Napoleon III (as the Prince-President of France) decided to rebuild the streets of Paris, creating healthier neighbourhoods. Georges-Eugène Haussmann, the prefect of the Seine département, led this mission and redesigned Paris to bring air and sunlight to the dense urban grid. More than 12,000 buildings were demolished, resulting in the present-day long avenues and tree-filled parks. An elaborate sewage system was also introduced [23,24]. Between 1853 and 1870, the sewage system in Paris increased about fourfold, with larger and wider ducts and an innovative cleaning system [42].

Tuberculosis was a disease that invaded Europe in the nineteenth century, also known as the "White Plague". Tuberculosis experts believed in the healing properties of sunlight and air. These aspects quickly led architects to rethink the design of buildings [43]. Le Corbusier, one of the pioneers of modern architecture, designed his projects to have more sunlight and air, and one of the ways he achieved this was through balconies, terraces or flat roofs that people could enjoy [44].

Between the middle of the nineteenth century and the beginning of the twentieth century, following the emergence of tuberculosis, specialised institutions, such as sanatoriums, began to appear. These institutions received patients with long-term illnesses, mostly tuberculosis, who were thus kept isolated from society while being treated. These buildings were erected in wooded and airy, high places, providing a privileged contact with nature [45]. Most of the sanatoriums incorporated modernist aspects. They were built with large balconies and flat roofs, where patients could enjoy greater exposure to sunlight and fresh air [43,46]. The environment of the sanatoriums even inspired one of the most influential novels of the twentieth century, Magic Mountain by Thomas Mann, whose story is set in a sanatorium in Davos, in the Swiss Alps [47].

Reclining chairs, known as sun loungers, started to appear, also associated with modernism. These curved chairs, generally made of wood, had an adjustable back and footrest and were very relaxing, making them ideal for use in sanatoriums [43]. 
Another relevant aspect was the emergence of the "summer house", also known as a garden house, shelter or teahouse. By the 1900s, the garden house was an extra "room" for the storage of garden equipment, such as sun loungers and for undertaking outdoor activities. But it was also an essential element in the treatment of tuberculosis, which could be used to isolate a sick family member. Not only was the patient isolated, but he/she could also enjoy the air and sunlight to help cure the disease [43].

Tuberculosis gave an influential boost to the modern architecture movement, highlighting particular architectural aspects, such as flat roofs, terraces and balconies [43].

The Spanish flu was one of several pandemics caused by the influenza virus that hit Europe. The outbreak that ravaged the continent between 1918 and 1919 was responsible for the deaths of 40 million people worldwide [48].

At the time, the field of epidemiology was growing, and there was a greater focus on the application of public health measures, compared to other outbreaks. The measures were not limited to imposing quarantine for potentially infected people. There was also a focus on the application of social distancing measures through the closure of various public spaces, such as churches, theatres and schools [14]. The wearing of a gauze mask was also one of the measures used to control the pandemic in USA cities [49].

More recently, in what we call modern times, there was a first severe acute respiratory syndrome (SARS) pandemic, caused by the coronavirus family (SARS-CoV-1). The pandemic started in 2003 [14]. Despite its high mortality rate, the pandemic was quickly controlled, with around 8000 cases being reported in 26 different countries after 8 months, mostly in China [3].

Once again, the containment measures that were applied were based on social distancing and quarantine. Many public spaces were closed, mainly in the most seriously affected cities in China. In some places, the taking of people's temperatures was made mandatory, as, for example, at the entrance of supermarkets [3].

The SARS-CoV-1 pandemic raised the question of the influence of built environments on pandemic control, including residential buildings and hospitals. In Hong Kong, one of the cities most badly affected by the pandemic, research has identified the role played by buildings in the spread of the virus, with a focus on improving ventilation and drainage systems [50].

\subsection{Urban Areas and Buildings Affect the Spread of Infectious Diseases}

If the health system discovers vaccines or treatment for diseases, the need for changes in other areas (such as the built environment) is reduced. Smallpox was responsible for an average of $6 \%$ of deaths (1670-1810) due to the increase in densely populated urban areas, which had poor nutrition levels, among other problems [51]. More hygienic and comfortable housing conditions made it possible to limit infections, while the vaccines discovered in the twentieth century made it possible to reduce or even eradicate the disease.

The (formal or informal) design of heavily populated urban areas can help to either increase or decrease the probability of infection, depending on the infrastructure and other living conditions. Extended urbanisation, with the creation of more informal public areas, increases vulnerability to infectious diseases, due to demographic factors, infrastructure and governance [52].

Not only does the built environment play a part in either increasing or decreasing infectious conditions (e.g., a lake of water or poor air ventilation), but, in some specific cases, it can actually create diseases. Legionnaire's disease is an example in which the air conditioning (HVAC), indoor plumbing and hot water systems can create new conditions for the spread of a specific disease [15].

The most relevant results of previous analyses about historical pandemic diseases are summarised in Table 1, below, presenting the main measures taken according to the behaviour that was adopted, the respective built environments and other measures. 
Table 1. Pandemic infectious diseases and their implications for the built environment.

\begin{tabular}{|c|c|c|c|c|}
\hline $\begin{array}{l}\text { Epidemiological } \\
\text { Disease }\end{array}$ & $\begin{array}{l}\text { Dimension (\% of World } \\
\text { or Regions) and Time } \\
\text { of Duration }\end{array}$ & Behaviour & $\begin{array}{c}\text { Built Environment } \\
\text { (Infrastructure, Buildings, } \\
\text { Urban Areas, } \\
\text { Green Spaces) }\end{array}$ & Ref. \\
\hline \multirow{2}{*}{$\begin{array}{l}\text { Infectious diseases in } \\
\text { the Roman Empire } \\
\text { (second century) }\end{array}$} & \multirow[b]{2}{*}{-} & $\begin{array}{l}\text { Isolation tents near } \\
\text { hospitals. }\end{array}$ & - & [29] \\
\hline & & - & $\begin{array}{l}\text { Infrastructure: Aqueducts, } \\
\text { public baths, division of } \\
\text { water and } \\
\text { sanitation systems. }\end{array}$ & [30] \\
\hline \multirow{3}{*}{$\begin{array}{l}\text { Black Death } \\
\text { (fourteenth } \\
\text { century) }\end{array}$} & \multirow{3}{*}{$\begin{array}{l}\text { Three pandemics } \\
\text { responsible for the death } \\
\text { of } 50-75 \text { million people } \\
\text { worldwide [14]. }\end{array}$} & $\begin{array}{l}\text { Quarantine and } \\
\text { restrictions on } \\
\text { movements. Closure of } \\
\text { public baths and advice } \\
\text { to avoid contact } \\
\text { with animals. }\end{array}$ & - & [33] \\
\hline & & Closure of ports. & & [32] \\
\hline & & - & $\begin{array}{l}\text { Urban planning begins to } \\
\text { create more space between } \\
\text { buildings-Elimination of } \\
\text { dirty and cramped } \\
\text { neighbourhoods. Larger } \\
\text { public spaces with more } \\
\text { organised layouts. }\end{array}$ & [35] \\
\hline \multirow{4}{*}{$\begin{array}{l}\text { Cholera (nineteenth } \\
\text { century) }\end{array}$} & \multirow{4}{*}{$\begin{array}{l}\text { Six outbreaks between } \\
\text { nineteenth and twentieth } \\
\text { centuries, responsible for } \\
\text { millions of deaths ( } 50 \% \\
\text { fatality rate) [37]. }\end{array}$} & $\begin{array}{l}\text { Quarantine for } \\
\text { individuals and cargo } \\
\text { arriving at ports. }\end{array}$ & - & [37] \\
\hline & & - & $\begin{array}{l}\text { Green areas: Parks in the } \\
\text { middle of cities. }\end{array}$ & [40] \\
\hline & & - & $\begin{array}{l}\text { Urban design: Long } \\
\text { avenues and open spaces } \\
\text { (e.g., Paris). }\end{array}$ & {$[23,24]$} \\
\hline & & - & $\begin{array}{l}\text { Sanitation: Creation of } \\
\text { infrastructure with } \\
\text { improved sewage systems. }\end{array}$ & \\
\hline \multirow{3}{*}{$\begin{array}{l}\text { Tuberculosis } \\
\text { (nineteenth century) }\end{array}$} & \multirow{3}{*}{$\begin{array}{l}\text { The disease survived for } \\
\text { over } 70,000 \text { years, infecting } \\
\text { nearly } 2 \text { billion people } \\
\text { worldwide [53]. }\end{array}$} & Sanatoriums. & & [45] \\
\hline & & & $\begin{array}{l}\text { Building design: Terraces, } \\
\text { balconies and flat roofs. } \\
\text { Modern urban design. }\end{array}$ & {$[43,46]$} \\
\hline & & Social isolation. & $\begin{array}{l}\text { Building design: revolving } \\
\text { summer houses. Furniture: } \\
\text { reclining chairs. }\end{array}$ & [43] \\
\hline \multirow[t]{2}{*}{$\begin{array}{l}\text { Spanish Flu } \\
\text { (twentieth century, } \\
\text { 1918-1919) }\end{array}$} & \multirow[t]{2}{*}{$\begin{array}{l}\text { Was responsible for the } \\
\text { deaths of } 50 \text { million people } \\
\text { between 1918-1919 [14]. }\end{array}$} & $\begin{array}{l}\text { Social distancing } \\
\text { —closure of public spaces } \\
\text { (churches, } \\
\text { theatres, schools). }\end{array}$ & - & [14] \\
\hline & & Use of gauze masks. & - & [49] \\
\hline \multirow[b]{2}{*}{$\begin{array}{l}\text { SARS-CoV-1 } \\
\text { (twenty-first century, } \\
\text { 2003-2004) }\end{array}$} & \multirow[b]{2}{*}{$\begin{array}{l}8000 \text { cases and more than } \\
800 \text { deaths reported in } 26 \\
\text { different countries after } 8 \\
\text { months [3]. }\end{array}$} & $\begin{array}{l}\text { Quarantine and } \\
\text { social distancing. }\end{array}$ & - & [3] \\
\hline & & - & $\begin{array}{l}\text { Local building design: } \\
\text { Improved ventilation and } \\
\text { drainage systems in } \\
\text { specific areas of Asia } \\
\text { (e.g., Hong Kong). }\end{array}$ & [50] \\
\hline
\end{tabular}

Specific solutions were created, such as water supply systems in Roman times (second century), not only due to the need to fight infections, but also in order to improve living conditions and to create a new lifestyle model. These solutions were not applied worldwide over the following centuries 
because of the fall of the Roman Empire. The reasons for this are complex, perhaps resulting from a different lifestyle, and the lack of available technology, resources or knowledge.

The Black Death later led to an increase in spaces both in and between buildings and improved zoning, which perhaps not only had benefits in reducing the transmission of infections, but also in creating economic opportunities through the restructuring of markets.

Cholera had a greater impact on the design of urban areas (green spaces, wide avenues). Tuberculosis motivated changes in buildings (access to sunlight and balconies) and modern architecture, altering urban design with the introduction of compact, tall and narrow buildings and the creation of large (and green) public spaces. In the 1950s, with the discovery of antibiotics as a cure for tuberculosis, sanatoriums began to close, but their primary purpose, namely taking advantage of natural and peaceful areas with beautiful landscapes for rest and relaxation, was frequently maintained. Some of them have been adapted to new roles, operating as spas or hotels [54]. Their architectural features have also been preserved, with some of these establishments being converted into museums or even schools, such as the School of Architecture in Clermont-Ferrand [55]. These adaptations have challenged buildings and the built environment to become more flexible.

In the (twenty-first century) SARS-CoV-1 pandemic, only small changes occurred, and in very specific places, without any significant impact on the design of buildings and urban areas. Perhaps if this outbreak had been seen as a sign of future risks, the health system, society and the built environment could have been better prepared for the SARS-CoV-2 (COVID-19) pandemic.

Some cases motivated changes in urban areas (cholera), such as the construction of new sanitation infrastructures and improvements in urban planning and buildings (tuberculosis), with the emergence of new innovative architectural ideas (balconies, flat roofs, terraces). But others did not bring any major, or even minor, changes to the built environment. The changes implemented in buildings and urban areas (the built environment) are not associated with just one specific function (infections), but also involve other public health dimensions (air quality, comfort and others).

\section{Rethinking Buildings and Urban Areas for Integrating Potential Measures to Control the COVID-19 Pandemic}

\subsection{Urban Areas}

Cities are places where high population densities are in constant close contact with each other, which makes them ideal centres for the rapid spread of infectious diseases [56]. Urban design greatly influences the degree of interaction between people; in other words, the agglomeration of economic activities and services in specific areas, for example, causes a large part of the population to gather in small fractions of the overall space. Furthermore, the differentiation between housing areas and workplaces creates the need for transport links [57].

These transport requirements lead to high rates of use of public transport. And public transport is also a high-risk environment for the spread of infectious diseases, due to the large number of people gathered together in a confined environment [58].

Urban design can be an essential factor for improving public health [56]. Thus, in the context of the COVID-19 pandemic, Table 2 presents some potential solutions that can be adopted in urban areas to mitigate the spread of infectious diseases and create conditions to enhance public health.

Five different components of urban spaces are considered: street paths (pedestrian pathways, cycle tracks), public equipment (e.g., urban furniture), public transport, green areas and information technologies. 
Table 2. Urban areas: potential measures in the built environment to prevent the spread of COVID-19.

\begin{tabular}{|c|c|c|c|c|}
\hline $\begin{array}{l}\text { Built Environment } \\
\text { System }\end{array}$ & Measure & COVID-19 Benefits & $\begin{array}{l}\text { Resilience (to Other } \\
\text { Vulnerabilities) }\end{array}$ & Sustainability \\
\hline \multirow[b]{2}{*}{ Street paths } & $\begin{array}{l}\text { Unidirectional } \\
\text { pedestrian paths [59]. }\end{array}$ & $\begin{array}{l}\text { Avoids people } \\
\text { crossing with one } \\
\text { another. }\end{array}$ & \multirow{2}{*}{$\begin{array}{l}\text { Useful for preventing } \\
\text { the transmission of } \\
\text { other infectious } \\
\text { diseases between } \\
\text { people. }\end{array}$} & $\begin{array}{l}\text { The contribution is } \\
\text { highly dependent on } \\
\text { the adopted solution. }\end{array}$ \\
\hline & $\begin{array}{l}\text { Wider pedestrian paths: } \\
\text { reducing the width of } \\
\text { roads (temporarily or } \\
\text { not) and increasing } \\
\text { pedestrian areas and } \\
\text { cycle tracks [59]. }\end{array}$ & $\begin{array}{l}\text { Allows for safe } \\
\text { distances between } \\
\text { people. }\end{array}$ & & $\begin{array}{l}\text { Increases mobility and } \\
\text { reduces carbon } \\
\text { emissions. }\end{array}$ \\
\hline \multirow{5}{*}{ Public equipment } & $\begin{array}{l}\text { Safety (distance) markers } \\
\text { on benches. }\end{array}$ & $\begin{array}{l}\text { Allows for safe } \\
\text { distances between } \\
\text { people. }\end{array}$ & $\begin{array}{l}\text { Useful for preventing } \\
\text { the transmission of } \\
\text { other infectious } \\
\text { diseases. }\end{array}$ & $\begin{array}{l}\text { Less space available for } \\
\text { services. }\end{array}$ \\
\hline & $\begin{array}{l}\text { Distribution of public } \\
\text { disinfectant containers or } \\
\text { washing infrastructures } \\
\text { in strategic locations [59]. }\end{array}$ & Public hygiene. & $\begin{array}{l}\text { Useful for preventing } \\
\text { the transmission of } \\
\text { other infectious } \\
\text { diseases. }\end{array}$ & $\begin{array}{l}\text { Greater use of cleaning } \\
\text { (disinfection) products. }\end{array}$ \\
\hline & $\begin{array}{l}\text { More local services } \\
\text { (energy, food). }\end{array}$ & $\begin{array}{l}\text { Decentralisation of } \\
\text { services and greater } \\
\text { local supply. }\end{array}$ & $\begin{array}{l}\text { Ensures basic services } \\
\text { available for any } \\
\text { extreme situation. }\end{array}$ & $\begin{array}{l}\text { Reduces the need for } \\
\text { people to travel } \\
\text { (benefits in terms of } \\
\text { reduced energy } \\
\text { consumption and } \\
\text { associated emissions). }\end{array}$ \\
\hline & $\begin{array}{l}\text { New pop-up service } \\
\text { points: bicycle repairs } \\
\text { and free water for } \\
\text { cyclists and walkers [60]. }\end{array}$ & \multicolumn{2}{|c|}{ Motivates and supports active mobility. } & $\begin{array}{l}\text { Increases mobility and } \\
\text { reduces carbon } \\
\text { emissions. }\end{array}$ \\
\hline & $\begin{array}{l}\text { Roller handrail } \\
\text { disinfection system [60]. }\end{array}$ & Disinfection of a comn & on contact surface & $\begin{array}{l}\text { Ecological and } \\
\text { economic balance. }\end{array}$ \\
\hline \multirow{6}{*}{$\begin{array}{l}\text { Public transport } \\
\text { facilities }\end{array}$} & $\begin{array}{l}\text { Protective barriers for } \\
\text { public transport drivers } \\
\text { (buses, trams) }[58,61] .\end{array}$ & $\begin{array}{l}\text { Physical protection to } \\
\text { avoid social contact. }\end{array}$ & $\begin{array}{l}\text { Useful for other } \\
\text { vulnerabilities, such as } \\
\text { robberies. }\end{array}$ & $\begin{array}{l}\text { Potentially less space } \\
\text { available. }\end{array}$ \\
\hline & Automatic doors [58]. & $\begin{array}{l}\text { Avoids contact with } \\
\text { common surfaces. }\end{array}$ & $\begin{array}{l}\text { Useful for other public } \\
\text { health vulnerabilities. }\end{array}$ & $\begin{array}{l}\text { Must ensure } \\
\text { appropriate use for all. }\end{array}$ \\
\hline & $\begin{array}{l}\text { Differentiation between } \\
\text { entrance and exit } \\
\text { doors [58]. }\end{array}$ & $\begin{array}{l}\text { Avoids people } \\
\text { crossing with one } \\
\text { another. }\end{array}$ & $\begin{array}{l}\text { Useful for other public } \\
\text { health vulnerabilities. }\end{array}$ & $\begin{array}{l}\text { Potentially less space } \\
\text { available. }\end{array}$ \\
\hline & $\begin{array}{l}\text { Safety distance markers } \\
\text { between seats. }\end{array}$ & Social distancing. & $\begin{array}{l}\text { Useful for other public } \\
\text { health vulnerabilities. }\end{array}$ & $\begin{array}{l}\text { Potentially less space } \\
\text { available. Reduces } \\
\text { energy consumption } \\
\text { and cost efficiency. }\end{array}$ \\
\hline & $\begin{array}{l}\text { Safety distance markers } \\
\text { at stops and in waiting } \\
\text { areas [62]. }\end{array}$ & Social distancing. & $\begin{array}{l}\text { Useful for other public } \\
\text { health vulnerabilities. }\end{array}$ & $\begin{array}{l}\text { Potentially less space } \\
\text { available. }\end{array}$ \\
\hline & $\begin{array}{l}\text { Public disinfectant } \\
\text { containers [58]. }\end{array}$ & Public hygiene. & $\begin{array}{l}\text { Useful for other public } \\
\text { health vulnerabilities. }\end{array}$ & $\begin{array}{l}\text { Ecological and } \\
\text { economic balance. }\end{array}$ \\
\hline $\begin{array}{l}\text { Green areas and } \\
\text { nature-based } \\
\text { solutions }\end{array}$ & $\begin{array}{l}\text { Natural environments in } \\
\text { urban areas [63]. }\end{array}$ & \multicolumn{2}{|c|}{$\begin{array}{l}\text { Could improve public health and may also } \\
\text { mitigate the effects of climate change [63]. }\end{array}$} & $\begin{array}{l}\text { Biodiversity and } \\
\text { climate change. }\end{array}$ \\
\hline $\begin{array}{l}\text { Information } \\
\text { technology } \\
\text { (smart cities) }\end{array}$ & $\begin{array}{l}\text { Integrates risk of new } \\
\text { infections in IoT (Internet } \\
\text { of things) approaches. }\end{array}$ & $\begin{array}{l}\text { Risk identification } \\
\text { (apps) and potential } \\
\text { reduction in } \\
\text { transmission through } \\
\text { greater information. }\end{array}$ & $\begin{array}{l}\text { Increases resilience, } \\
\text { especially if the } \\
\text { information allows } \\
\text { governance with users. }\end{array}$ & $\begin{array}{l}\text { Reduces the need } \\
\text { for resources. }\end{array}$ \\
\hline
\end{tabular}




\subsection{Buildings}

Dietz (2019) analyses several aspects that can reduce the possibility of SARS-CoV-2 (COVID-19) transmission inside buildings, focusing on aspects such as ventilation and indoor air quality, lighting and the deposition on the surfaces of materials [18]. Indeed, there seems to be some consensus as to how certain indoor air quality conditions, especially the specific features of the HVAC system [64] or relative humidity $[65,66]$, can influence virus activity.

Some studies show the effectiveness of certain materials in reducing the lifetime of the virus on their surfaces $[67,68]$ and others relate the level of natural light in the building with the activity of the virus [69]. There is also some discussion about the influence of wastewater and waste collection systems on the transmission of SARS-CoV-2 [70]. Table 3 presents the potential measures that could be implemented in buildings. 
Table 3. Potential measures for reducing COVID-19 transmission in buildings and other built environment dimensions.

\begin{tabular}{|c|c|c|c|c|c|}
\hline $\begin{array}{l}\text { Main } \\
\text { Group }\end{array}$ & $\begin{array}{l}\text { Group } \\
\text { Elements }\end{array}$ & Measure & COVID-19 Benefits & $\begin{array}{l}\text { Resilience (to COVID-19 and Other } \\
\text { Vulnerabilities) }\end{array}$ & Sustainability \\
\hline \multirow[b]{2}{*}{ Structure } & Foundations & - & - & \multicolumn{2}{|c|}{ Reduces risk: seismic, wind and landslides. Flexibility. } \\
\hline & $\begin{array}{l}\text { Basement } \\
\text { construction }\end{array}$ & - & - & \multicolumn{2}{|c|}{ Reduces risk: seismic, wind and landslides. Flexibility. } \\
\hline \multirow{4}{*}{ Shell } & Super structure & - & - & \multicolumn{2}{|c|}{ Reduces risk: seismic, wind and landslides. Flexibility. } \\
\hline & $\begin{array}{l}\text { Exterior } \\
\text { Enclosure }\end{array}$ & $\begin{array}{l}\text { Sunlight (achieved through } \\
\text { orientation, glazed openings } \\
\text { and open blinds). }\end{array}$ & \multicolumn{2}{|c|}{$\begin{array}{l}\text { Although there is no evidence of the effect of sunlight on } \\
\text { SARS-CoV-2 [71], some viruses, such as influenza, are sensitive to } \\
\text { sunlight [69]. }\end{array}$} & $\begin{array}{l}\text { Good bioclimatic and energy } \\
\text { performance. }\end{array}$ \\
\hline & & $\begin{array}{l}\text { Providing a window with a } \\
\text { view. }\end{array}$ & \multicolumn{3}{|c|}{$\begin{array}{l}\text { Windows are the main point of contact with the exterior of the } \\
\text { building. Pleasant views (e.g., the surrounding nature) can influence } \\
\text { psychological well-being (increased concentration, reduced stress, } \\
\text { comfort, emotions) [72]. }\end{array}$} \\
\hline & Roofing & $\begin{array}{l}\text { Potential openings for light or } \\
\text { roof access. }\end{array}$ & $\begin{array}{l}\text { Promotes natural } \\
\text { lighting-potential } \\
\text { outside uses. }\end{array}$ & \multicolumn{2}{|l|}{ Guarantees physical and thermal protection. } \\
\hline \multirow[b]{3}{*}{ Interiors } & $\begin{array}{l}\text { Interior } \\
\text { construction }\end{array}$ & $\begin{array}{l}\text { Hands-free door opening } \\
\text { (e.g., using elbow or foot) [73]. }\end{array}$ & $\begin{array}{l}\text { Avoids using your ha } \\
\text { of spreading SARS-Cc }\end{array}$ & $\begin{array}{l}\text { Is to open the doors, reducing the possibility } \\
\text { - } 1 \text { and other viruses. }\end{array}$ & Access to all. \\
\hline & \multirow[b]{2}{*}{ Interior finishes } & $\begin{array}{l}\text { Easy to clean (homogeneous } \\
\text { without pores). }\end{array}$ & $\begin{array}{l}\text { Easy to eliminate SAR } \\
\text { contaminations. }\end{array}$ & -CoV-2 and other pathogens, avoiding other & $\begin{array}{l}\text { Fewer cleaning products and } \\
\text { lower toxicity. }\end{array}$ \\
\hline & & $\begin{array}{l}\text { Selection of materials that } \\
\text { reduce virus's residence time* } \\
\text { (e.g., copper and others) [67]. }\end{array}$ & \multicolumn{2}{|c|}{$\begin{array}{l}\text { Positive for reducing residence time (or avoiding accommodation) of } \\
\text { SARS-CoV-2 and other pathogens, avoiding other contaminations. }\end{array}$} & $\begin{array}{l}\text { Important that LCA (Life cycle } \\
\text { Assessment) and LCC (Life } \\
\text { Cycle Cost) have a good } \\
\text { balance for each functional } \\
\text { unit, for example, recycled } \\
\text { materials. }\end{array}$ \\
\hline
\end{tabular}


Table 3. Cont.

\begin{tabular}{|c|c|c|c|c|}
\hline $\begin{array}{l}\text { Main } \\
\text { Group }\end{array}$ & $\begin{array}{l}\text { Group } \\
\text { Elements }\end{array}$ & Measure & $\begin{array}{l}\text { Resilience (to COVID-19 and Other } \\
\text { Vulnerabilities) }\end{array}$ & Sustainability \\
\hline \multirow{9}{*}{ Services } & \multirow[b]{2}{*}{ Conveying } & $\begin{array}{l}\text { Lifts: safe distance markers }(2 \mathrm{~m}) \text {, } \\
\text { depending on the lift } \\
\text { capacity [19]. }\end{array}$ & $\begin{array}{l}\text { It allows social distancing, preventing the spread of SARS-CoV-2 and } \\
\text { other viruses. }\end{array}$ & $\begin{array}{l}\text { More energy spent per person } \\
\text { (reducing lift capacity). }\end{array}$ \\
\hline & & $\begin{array}{l}\text { Stairs allow passage to different } \\
\text { floors (one way). Distance and } \\
\text { direction markers on stairs. }\end{array}$ & $\begin{array}{l}\text { Unidirectional circulation could reduce the risk of contact. Stairs } \\
\text { ensure social distancing and direction. }\end{array}$ & $\begin{array}{l}\text { Reduces risk of infection, but } \\
\text { could create problems in } \\
\text { emergencies, such as fires. } \\
\text { Lowers the capacity of } \\
\text { service use. }\end{array}$ \\
\hline & \multirow{3}{*}{$\begin{array}{l}\text { Water } \\
\text { system }\end{array}$} & Water system. & Ensures appropriate hygiene conditions. & $\begin{array}{l}\text { Balance between water supply } \\
\text { requirements and the reduction } \\
\text { of potable water consumption. }\end{array}$ \\
\hline & & Routine wastewater testing. & $\begin{array}{l}\text { This can be used to detect the presence of SARS-CoV-2, but also other } \\
\text { viruses, indicating the risk of contagion [70]. }\end{array}$ & Reduces risks. \\
\hline & & $\begin{array}{l}\text { Wastewater disinfection: } \\
\text { residual free chlorine }(>0.5 \\
\mathrm{mg} / \mathrm{L}) \text {, residual chlorine dioxide } \\
(>2.19 \mathrm{mg} / \mathrm{L}) \text { or } \mathrm{UV} \\
\text { radiation }[74] .\end{array}$ & $\begin{array}{l}\text { Chen et al. (2006) concluded that disinfection by UV radiation and } \\
\text { chlorine dioxide were the most efficient means of fighting } \\
\text { SARS-CoV-1 [74]. It may be effective against other viruses. }\end{array}$ & Reduces risks. \\
\hline & \multirow{4}{*}{ HVAC } & $\begin{array}{l}\text { Mixed modes, with natural } \\
\text { ventilation. }\end{array}$ & $\begin{array}{l}\text { Constant air renewal to reduce the possibility of the virus remaining in } \\
\text { the form of aerosolised particles inside the building [64]. Other } \\
\text { psychological benefits. }\end{array}$ & \multirow{4}{*}{$\begin{array}{l}\text { Besides reducing the risk of the } \\
\text { virus and other } \\
\text { microorganisms, allows for the } \\
\text { elimination of certain polluting } \\
\text { particles. Potential energy } \\
\text { saving measures. }\end{array}$} \\
\hline & & $\begin{array}{l}\text { HEPA (high-efficiency } \\
\text { particulate air) filters [75]. }\end{array}$ & $\begin{array}{l}\text { Capable of removing at least } 99.97 \% \text { of particles with sizes starting } \\
\text { from } 0.3 \mu \mathrm{m} \text { [75]. }\end{array}$ & \\
\hline & & Heat recovery unit [64]. & \multirow[t]{2}{*}{ Ensures good air quality. } & \\
\hline & & $40-60 \%$ relative humidity [66]. & & \\
\hline
\end{tabular}


Table 3. Cont.

\begin{tabular}{|c|c|c|c|c|c|}
\hline $\begin{array}{l}\text { Main } \\
\text { Group }\end{array}$ & $\begin{array}{l}\text { Group } \\
\text { Elements }\end{array}$ & Measure & COVID-19 Benefits & $\begin{array}{l}\text { Resilience (to COVID-19 and Other } \\
\text { Vulnerabilities) }\end{array}$ & Sustainability \\
\hline \multirow{5}{*}{ Services } & $\begin{array}{l}\text { Risk protection } \\
\text { systems }\end{array}$ & $\begin{array}{l}\text { Enlarges the risk protection } \\
\text { system to include infectious } \\
\text { diseases (thermal sensors). }\end{array}$ & $\begin{array}{l}\text { Detects the presence of the } \\
\text { virus. }\end{array}$ & $\begin{array}{l}\text { Enlarges the risk detection system and } \\
\text { actions to other dimensions. }\end{array}$ & $\begin{array}{l}\text { Strong contribution to risk } \\
\text { identification. }\end{array}$ \\
\hline & Energy systems & $\begin{array}{l}\text { Reliable power supply ensures } \\
\text { that not only core systems for the } \\
\text { management of health } \\
\text { programmes can function } \\
\text { effectively, but also the specific } \\
\text { building's needs. }\end{array}$ & $\begin{array}{l}\text { Ensures appropriate function } \\
\text { conditions (air conditioning } \\
\text { if necessary). }\end{array}$ & $\begin{array}{l}\text { All activities are highly dependent on } \\
\text { access to a reliable energy supply. } \\
\text { The creation of a local renewable supply } \\
\text { could help to increase the resilience of } \\
\text { systems. }\end{array}$ & $\begin{array}{l}\text { Potential opportunities for } \\
\text { low carbon consumption } \\
\text { (renewable energy) and/or } \\
\text { local energy supply system. }\end{array}$ \\
\hline & \multirow[t]{2}{*}{$\begin{array}{l}\text { Information } \\
\text { systems }\end{array}$} & $\begin{array}{l}\text { Information technology makes it } \\
\text { possible to manage situations } \\
\text { and users. }\end{array}$ & $\begin{array}{l}\text { Reduces presence, optimises } \\
\text { ventilation and other options. }\end{array}$ & $\begin{array}{l}\text { Some devices can simultaneously } \\
\text { reduce unnecessary energy and water } \\
\text { consumption. Fewer disinfection } \\
\text { products needed. }\end{array}$ & $\begin{array}{l}\text { Prevents polluting } \\
\text { aerosolised particles from } \\
\text { remaining in the air longer, } \\
\text { due to dry environments. }\end{array}$ \\
\hline & & $\begin{array}{l}\text { Touch-free technologies } \\
\text { (switches and bathroom } \\
\text { equipment). }\end{array}$ & $\begin{array}{l}\text { Technologies, such as } \\
\text { smartphone controls, motion } \\
\text { sensors and voice controls, } \\
\text { reduce the need for contact } \\
\text { with various common } \\
\text { surfaces and reduce the } \\
\text { spread of pathogens. }\end{array}$ & $\begin{array}{l}\text { Makes it possible to control other risks. } \\
\text { Reduces manual control. }\end{array}$ & $\begin{array}{l}\text { An optimisation solution } \\
\text { could enable the user to } \\
\text { control the programme by } \\
\text { voice, in order to reduce the } \\
\text { consumption of resources. }\end{array}$ \\
\hline & Waste & $\begin{array}{l}\text { Specific (separate) collection for } \\
\text { quarantined houses or areas with } \\
\text { outbreaks of contagion: } \\
\text { Incineration and strict } \\
\text { disinfection of collection } \\
\text { vehicles [70]. }\end{array}$ & $\begin{array}{l}\text { The virus can remain on } \\
\text { plastic and other surfaces for } \\
\text { several days. Rubbish bags } \\
\text { can be a potential vector of } \\
\text { transmission. Special care in } \\
\text { areas with high risk of } \\
\text { contagion can prevent other } \\
\text { infections [70]. }\end{array}$ & $\begin{array}{l}\text { Lower activity reduces the amount of } \\
\text { waste in landfills but also reduces } \\
\text { recycling. Incineration emits } \\
\text { polluting gases. }\end{array}$ & $\begin{array}{l}\text { Depends on the solution } \\
\text { and whether it is integrated } \\
\text { into a lower consumption } \\
\text { of resources and improves } \\
\text { recyclability. }\end{array}$ \\
\hline
\end{tabular}


Table 3. Cont.

\begin{tabular}{|c|c|c|c|c|c|c|}
\hline $\begin{array}{l}\text { Main } \\
\text { Group }\end{array}$ & Group Elements & Measure & COVID-19 Benefits & \multicolumn{2}{|c|}{$\begin{array}{l}\text { Resilience (to COVID-19 and } \\
\text { Other Vulnerabilities) }\end{array}$} & Sustainability \\
\hline \multirow{4}{*}{$\begin{array}{l}\text { Equipment } \\
\text { and } \\
\text { furniture }\end{array}$} & \multirow{3}{*}{ Equipment } & Ensures easy cleaning solutions. & Reduces the risk of cross contamir & lation & & Fewer disinfection products. \\
\hline & & $\begin{array}{l}\text { Select materials that reduce the } \\
\text { virus's residence time } \\
\text { (e.g., copper) [67]. }\end{array}$ & $\begin{array}{l}\text { Positive for reducing residence } \\
\text { time (or avoiding } \\
\text { accommodation) of SARS-CoV-1 } \\
\text { and other pathogens, preventing } \\
\text { other contaminations. }\end{array}$ & \multicolumn{3}{|c|}{$\begin{array}{l}\text { Important that LCA and LCC have a good balance for each } \\
\text { functional unit, for example, recycled materials. }\end{array}$} \\
\hline & & $\begin{array}{l}\text { Minimalist solutions, fewer places } \\
\text { that can offer a pathway to the } \\
\text { virus. }\end{array}$ & $\begin{array}{l}\text { Reducing places of } \\
\text { contamination could reduce the } \\
\text { potential for contamination. }\end{array}$ & \multicolumn{2}{|c|}{$\begin{array}{l}\text { Fewer objects lead to more flexible } \\
\text { solutions and prevent objects from } \\
\text { falling. }\end{array}$} & $\begin{array}{l}\text { Reduction of materials. If } \\
\text { less toxic LCA is reduced and } \\
\text { LCC is good, this could be a } \\
\text { sustainable positive } \\
\text { direction. }\end{array}$ \\
\hline & Furniture & Avoid using carpets and rugs [76]. & \multicolumn{3}{|c|}{$\begin{array}{l}\text { Helps to reduces the concentration of pathogenic agents inside the } \\
\text { building. }\end{array}$} & $\begin{array}{l}\text { Positive, if fewer, impacts in } \\
\text { life cycle. }\end{array}$ \\
\hline \multirow{2}{*}{$\begin{array}{l}\text { Building } \\
\text { divisions }\end{array}$} & Entrance & $\begin{array}{l}\text { Flexible entrance (to be adapted to } \\
\text { a decontamination zone), with } \\
\text { washbasins at the entrance (or in } \\
\text { bathroom) [62]. }\end{array}$ & \multicolumn{3}{|c|}{$\begin{array}{l}\text { Prevents pathogens from entering the main building divisions (either } \\
\text { through potentially contaminated clothing or objects, or by hand). }\end{array}$} & - \\
\hline & Room & $\begin{array}{l}\text { Extra room for occupants who } \\
\text { need to isolate [62] (preferably } \\
\text { with private bathroom). }\end{array}$ & \multicolumn{3}{|c|}{$\begin{array}{l}\text { Isolation of potentially contaminated residents. Reduces risk of } \\
\text { contagion from SARS-CoV-1 and other infections. }\end{array}$} & $\begin{array}{l}\text { Increases the space per } \\
\text { building and the energy } \\
\text { consumption (as costs). }\end{array}$ \\
\hline \multirow[t]{2}{*}{$\begin{array}{l}\text { External } \\
\text { spaces }\end{array}$} & $\begin{array}{l}\text { Balconies, } \\
\text { terraces, flat roofs }\end{array}$ & $\begin{array}{l}\text { Provides at least one outdoor area, } \\
\text { with considerable space. }\end{array}$ & \multicolumn{3}{|c|}{$\begin{array}{l}\text { Allows people to take physical exercise, get fresh air and sunlight, } \\
\text { while avoiding social contact. } \\
\text { Fresh air [77] and vitamin D are beneficial for human health, including } \\
\text { respiratory problems [78], even more so in confinement situations. }\end{array}$} & $\begin{array}{l}\text { Thermal bridge care. } \\
\text { Can be used for food } \\
\text { production and other } \\
\text { activities [26]. }\end{array}$ \\
\hline & $\begin{array}{l}\text { Home gardens for } \\
\text { food production }\end{array}$ & $\begin{array}{l}\text { Uses external spaces for home } \\
\text { gardens. }\end{array}$ & \multicolumn{4}{|c|}{ Food production with economic, recreational and health benefits [26]. } \\
\hline Landscape & $\begin{array}{l}\text { Immediate } \\
\text { surroundings }\end{array}$ & $\begin{array}{l}\text { Health-promoting landscapes } \\
\text { (natural green landscapes, offering } \\
\text { conditions of security and } \\
\text { connectivity, as well as several } \\
\text { amenities, including physical } \\
\text { exercise equipment) [79]. }\end{array}$ & \multicolumn{2}{|c|}{$\begin{array}{l}\text { Landscapes influence health and well-being. They } \\
\text { have the potential to promote mental health, reduce } \\
\text { stress, raise happiness levels and promote social } \\
\text { cohesion, as well as offering physiological benefits. }\end{array}$} & \multicolumn{2}{|c|}{$\begin{array}{l}\text { Maintenance of ecosystem services, } \\
\text { preparation for adaptation to climate change, } \\
\text { guarantee of other functionalities. }\end{array}$} \\
\hline
\end{tabular}




\section{Discussion}

\subsection{Which Solutions will not be Merely Temporary?}

Great historical pandemics, like the Black Death [35], cholera [42] or tuberculosis [43], have leveraged changes designed to introduce protective measures into buildings and urban areas. There is some consensus as to how buildings, i.e., enclosed spaces where several people are brought together, are potential vectors for the transmission of infectious diseases, whether by airborne transmission or through aerosolised particles, such as those transmitted through touching common contact surfaces $[18,80]$.

With the advance of the COVID-19 pandemic, many countries have adopted various temporary mitigation measures, namely social distancing, quarantine and the closure of various public spaces, schools, restaurants, workplaces and cultural spaces [81].

Various types of measures (Tables 2 and 3) are already beginning to be considered and analysed, both for buildings and urban areas. For example: measures at the urban level to promote social distancing by widening pavements, one-way paths and social distance markers on public transport; in buildings, the selection of materials (in construction and furniture) that can reduce the residence time of the virus (e.g., copper) [67] and that are easy to clean, ventilation (components of the HVAC system [64,75] and related conditions, such as humidity [66]), waste management and wastewater monitoring [70]; an option for simple and minimalist interior designs, including the removal of carpets and rugs [76].

However, not all potential solutions will be easy to apply, making it important to consider the question from a holistic point of view and to realise what other benefits each solution can offer, namely in sustainable terms, as a contribution (or not) towards the lower consumption of resources (energy, water, materials), reduced emissions, greater biodiversity and economic value. So, the question as to whether these potential solutions will be adopted in the future and if they will be long-term solutions is a complex one to answer, depending on several factors.

In urban areas, active mobility in cities is a process that has been improving in the context of sustainable development. However, it is likely that some structural measures to further improve and promote active mobility will be implemented in several cities following the COVID-19 pandemic. Measures such as the widening of street pavements or one-way walking paths can be applied to ensure adequate levels of social distance [59], but they can also motivate people to adopt more active forms of mobility (walking, cycling, among others), thereby reducing the number of people using public transport. This helps to reduce the likelihood of contagious infectious diseases spreading among people, but also to reduce the use of public transport or personal motor vehicles, and their associated GHG (Greenhouse Gas) emissions.

As far as public equipment is concerned, there may be a promotion of hygiene care at the community level, with the distribution of small containers of disinfectant in strategic public places [59], or even disinfection systems for common contact surfaces, such as roller handrails [60]. This will be a solution that can contribute, in a way, to public health and hygiene, reducing the likelihood of virus infections. However, there are no other relevant contributions to sustainability, so this would imply a high consumption of disinfectant and regular maintenance (refilling) of the equipment.

Safe distance markers on urban furniture, such as public benches, could also be adopted. Nonetheless, their usefulness would only be short-term since they do not bring any other benefits apart from reducing the possibility of contagion between people through distance. These social distance measures that contribute only to the fight against COVID-19 could be lost as soon as the risk of contagion decreases, as was the case in previous pandemics, such as SARS-CoV-1.

The implementation of a more local provision of services (food, energy) may also become an increasing trend in large cities. To some extent, this contributes towards decentralisation and can restrict the formation of large clusters of people, a measure that can be beneficial in terms of preventing the transmission of infectious diseases, but also in reducing transport needs. However, this is a solution that needs to be adopted gradually over the medium term. 
Installing support structures for active mobility (bicycle repairs, water supply for cyclists) is another solution that could motivate active mobility [60], ultimately making a positive contribution to reducing the transmission of infectious diseases, as already discussed in relation to the question of street paths.

Some changes are to be expected in public transport, namely in relation to social distancing, with the use of safe distance markers (both at bus stops and on seats), and a differentiation between entrance and exit areas [58]. There should also be a reduction in the maximum capacity of means of transport, as this prevents the spread of COVID-19 or other highly infectious diseases. The use of protective barriers for drivers and workers [61], a measure that is already being applied in several countries, not only offers protection in terms of public health, but also against other risks, namely theft. This is a solution that remains open for consideration in the future. The use of automatic doors [58] is a solution that is easy to apply and is optimal for reducing common contact surfaces, although its benefits or drawbacks to sustainability should be explored.

There may be an investment made in increasing green areas in urban zones, indirectly contributing to the fight against COVID-19 by favouring public health, while also having enormous benefits in terms of sustainability. This solution should be implemented gradually in some urban areas, in keeping with the policies of sustainable development and the fight against climate change.

In information technologies, there may be an evolution, with the emergence of software applications for risk identification and gathering information about the potential reduction in the transmission of infectious diseases. These technologies, which provide possible lasting solutions, also bring benefits in terms of sustainability, since they reduce the need for other resources, although they could, however, represent a major challenge to privacy.

As far as the shell elements of buildings are concerned (roofs, external enclosures), the improvement of certain aspects in order to improve access to natural light (glazing, skylights, orientation) is a solution that presents benefits not only for reducing viral activity inside buildings [69], but also in terms of sustainability, by improving the bioclimatic performance of buildings. These solutions contribute indirectly to the fight against COVID-19 by improving public health conditions over a large timescale (25 years or more).

Windows are fundamental for the health of a building's occupants. [82]. In addition to allowing access to ventilation and sunlight, they are also the main point of contact with the outside, due to the visual connection that they provide. The view from windows can also make a spiritual contribution, depending on each person's perceptions, as well as offering other benefits that can be essential during periods of social distancing [83]. Providing a window with a view, preferably of a natural landscape, can have positive impacts on mental well-being, namely by reducing stress and increasing concentration and happiness indexes and the sense of comfort [72]. It is a solution that does not directly contribute to combating COVID-19, but it can strengthen people's psychological health.

In the case of building interiors (construction and finishing), regardless of their nature, the use of materials with a shorter residence time for the virus and the use of easily washable surfaces could effectively be a parameter in new buildings, especially in relation to common contact surfaces. The use of these materials (e.g., copper [67]) could be expensive, although it would bring essential benefits in terms of combating viral activity. It is considered that such a measure would reduce the residence time of the COVID-19 virus within the effective area, while it is further assumed that it would last at least 10 years. Hands-free door opening systems, an idea that has already been presented and discussed [73], is a solution that reduces the transmission of SARS-CoV-2 and other viruses, and it would increase accessibility for disabled people, even though it is not clear what other benefits this would bring in relation to other aspects of sustainability.

In conveyor systems or services, potential measures for reducing viral transmissions could be social distancing solutions (safe distance markers in lifts [19] and unidirectional stairs). Such measures would reduce some of the benefits to be enjoyed in other aspects, just as they would be relatively 
difficult to apply (mainly the one-way ascent or descent of stairs, due to the limited space in some buildings), and it would also reduce the capacity of services.

The implementation of these social distancing measures is hard to predict, because, as has already been mentioned, it is possible that when the risk of infection decreases, these benefits may be lost. It is assumed that the markers in the lifts will last for at least a year and that they are dependent on the continuation of the risk of transmission at the time. It is assumed that, since they involve certain construction requirements, the unidirectional stairs would last at least 10 years.

Wastewater management systems could be improved to reduce the risk of the spread of infectious diseases. The constant monitoring with quality testing may be justified to identify potential cases of infection in specific areas (in the case of diseases with faecal-oral transmission, such as COVID-19) [70]. This monitoring can also be useful for identifying the presence of other pathogens and even polluting particles. The suggested treatment proves effective in eliminating traces of the virus in wastewater and can be useful in eliminating other pathogens, and it could even provide a monitoring perspective of the COVID-19 situation [74]. While monitoring can be monthly, treatment should be performed daily.

Ventilation is a parameter that should be given more attention. Firstly, there is a need to rethink the situation of closed buildings that do not have flexible ventilation options. Constant ventilation is important in order to guarantee air circulation, reducing the time the virus stays in the building [18] and also reducing transmission, but it is also important to ensure good indoor air quality. In HVAC systems, on the other hand, some characteristics, such as convection cells and air handling units or filters [64], should be reconsidered due to the risks of cross-contamination.

Perhaps HVAC systems should have greater local extraction in order to guarantee a $100 \%$ indoor and outdoor air exchange, avoiding recirculation, contributing both to reducing viral transmission and better indoor air quality, but not providing as much protection as natural ventilation. Such features can easily be placed on the agenda and be considered as elements for potential certification, because they also improve the indoor air quality, but they will have an important impact on energy consumption, without any recovery heating or other measures. In short, it is a solution that would need supplementary investment and has a number of limitations in regard to its application. The same is true for the use of high-efficiency filters (HEPA) [75]. However, while these filters may have to be changed periodically (lifespan ranging from a month to a year), the remaining HVAC components will have a longer duration, around 10 years.

Further research into optimum conditions is expected to reduce the residence time of the virus in the form of aerosolised particles in closed environments, focusing on such questions as humidity or temperature. The levels of certain indoor air conditions, and humidity in particular, positively affect viral activity in the building and accelerate the deposition of other aerosolised particles [65], thus avoiding the inhalation of other pollutants or pathogens. Since this is a component of the air conditioning unit, it is considered to follow the same rationale as the heat recovery unit, with a duration of 10 years.

In systems that detect a series of risks, such as fire risk, for example, there may be an increase in the risks considered, so that systems can be implemented that also detect viruses or infectious diseases (e.g., thermal sensors). However, the constructs for sustainability need to be explored, as well as the level of investment that would be required. For an electronic system, it is assumed that such a solution would last for five years.

In energy systems, it is important to ensure that the energy continues to be supplied in the event of a pandemic, to prevent people from needing to leave. However, if the local energy production is renewable, it is useful both in terms of protecting against other vulnerabilities and for ensuring sustainability. The duration of this type of system is essential and it usually lasts for more than 10 years.

In information systems, the use of touch-free technologies (based on sensors, among other features) or digital control, substituting specific common contact surfaces like switches and other types of interfaces, should become a growing trend, in line with the current move towards the use of digitisation in construction [84]. It is a solution that has a positive effect in reducing viral transmission between 
humans, but it also has enormous benefits in terms of sustainability, allowing for a reduction in energy or water costs, for example. There may be a growth in information technologies, which not only make it possible to obtain information about public health, but can also be used to control indoor conditions and resources (energy, water). Based on the same logic as before, it is assumed that this solution would last for five years.

In the case of waste management in areas identified as representing a risk in terms of viral transmission, differentiated waste collection from buildings or specific places is potentially advantageous for reducing the transmission of infectious diseases and improving public health [70]. This measure also brings benefits in combating other risks and promoting public health and hygiene. Nonetheless, it is not easy to apply this measure, as it requires changes to the municipal waste collection systems. Its duration corresponds to the waste collection interval of each municipality (days).

Perhaps a simpler and cleaner minimalist design for buildings (typical of Nordic countries) will also become an increasing trend. The concept of minimalism and the banning of carpets and rugs could similarly reduce the accumulation of viruses inside the building [76], but the benefits that such solutions offer in terms of consuming fewer resources and requiring less maintenance could be very useful in terms of sustainability, depending on the adopted solution. Minimalism also makes spaces more flexible and adaptable. If the use of carpets is avoided, there is a further reduction in the use of materials (raw materials and cleaning products). It is assumed that such a measure would last for 10 years.

Perhaps the entrance to buildings should be rethought. Spacious and flexible entrances can be adapted into spaces for leaving clothes and potentially contaminated objects from the outside, and could even be equipped with washbasins [62] (or a bathroom immediately next to the entrance). This is a lasting solution that can essentially improve the hygiene and health of the building by preventing the entry of possible pathogens.

The existence of a small room to be used to isolate a resident infected with a highly transmissible disease, [62] preferably with a private bathroom, could also be a criterion for future collective housing buildings. It is a solution that has substantial benefits in preventing contagion. However, it requires more space per building and has higher energy costs.

The quarantine decreed by governments due to the COVID-19 pandemic may have shown how important it is to have access to an outside space to get air and sunlight (vitamin D) safely. Perhaps the existence of an external space (such as a balcony, terrace or even a flat roof) that is accessible to all residents may be a criterion for future buildings. These spaces can later be used as a kitchen garden, with economic and leisure benefits [26]. Besides providing advantages in terms of sustainability and other benefits, external spaces in new buildings could be used for sports and other activities. It may not be easy to create such spaces due to the building's limited capacity (and they may even be prohibited in the regulations), and there may be special requirements needed at the level of construction (thermal bridges and others). In some cases, balconies may be enclosed in order to improve thermal insulation; however, it is important to ensure that they continue to offer conditions for ventilation and for obtaining sunlight (openings).

Another important aspect is the question of the landscape, in other words, the building's surrounding environment. Abraham (2006) states that the characteristics of the landscape have the potential to promote health, as well as physical and mental well-being [85]. The presence of natural green spaces is one of the fundamental elements for reducing stress, increasing happiness levels, promoting the practice of physical activity and reducing air pollution and noise levels [86]. Other aspects, such as connectivity, security and the diversity of amenities, also make important contributions, especially regarding social interaction and well-being [85].

It is increasingly important to look at this aspect when thinking about the role that buildings can play in relation to human health. Although it is not a measure that directly reduces the transmission of SARS-CoV-2 or other viruses, it is nonetheless a solution that promotes public health in the long term and that may help to strengthen the population's immune system to some extent. 
At another level, there is a growing trend towards the construction of holistic, sustainable buildings and urban areas with a huge potential for disruptive leverage, not only improving resilience to infectious disease, but also responding to the challenges of climate change.

Figure 2, below, shows the ranking of these solutions for buildings and urban areas, according to the scales and evaluations explained in the methodology. This classification makes it possible to identify solutions that relate only to a reduction in the COVID-19 risk and others that are also beneficial in terms of other aspects of sustainability (win-win).

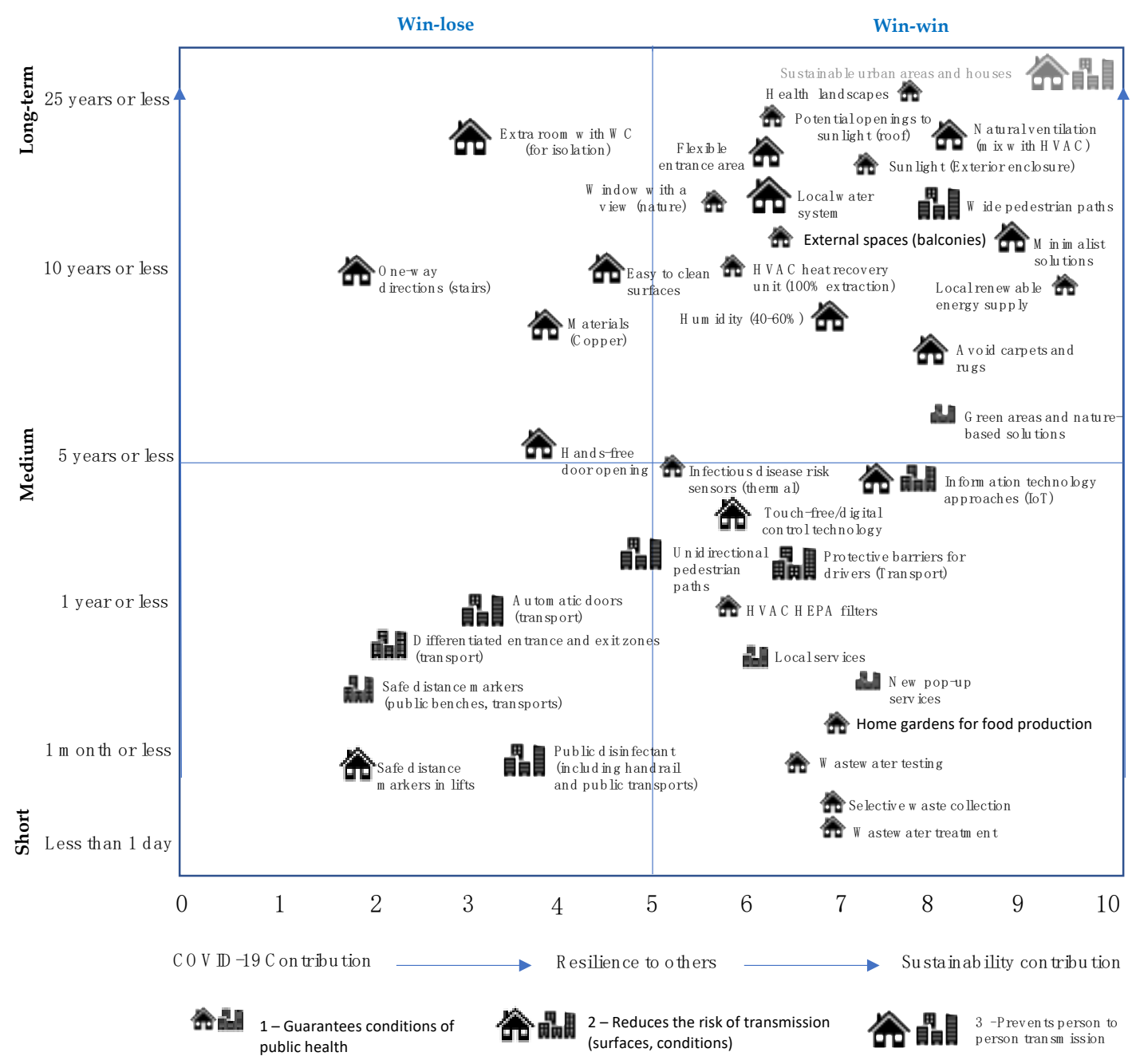

Figure 2. COVID-19 risk reduction measures in urban areas and buildings.

\subsection{Could COVID-19 Risk Control Measures Leverage a Sustainable Built Environment?}

The environmental balance of the COVID-19 outbreak reveals temporarily positive (lower energy consumption, fewer carbon emissions) and adverse effects (use of chemical reagents, viral wastewater contaminations, increases in medical waste, social poverty). Even so, the final balance depends on how this event is internalised by people [9].

Social confinement creates a win-lose relationship between health (staying at home) and the economy (reduced economic activity, reduced income, bankruptcy), social effects (unemployment) and potential gains in some environmental dimensions (lower energy consumption, fewer carbon emissions).

The COVID-19 outbreak provides clear evidence of the correlation between environmental impacts (pollution) and economic activity (GDP), which have not yet been decoupled. The challenge is to recalibrate the solutions and ensure a good environmental quality that will also benefit health [10]. 
The analysis of the win-win measures (Figure 2) identifies measures that are: (1) largely COVID-19 risk reduction measures that may primarily reduce the risk of transmission in potential conditions without any other benefits in terms of sustainability (win-lose); other measures that also allow for the improvement of some other aspects of sustainability, ranging from (2) incremental measures to (3) factorial measures with a win-win relationship that leverages a sustainable built environment and could even motivate disruptive changes and effective changes in terms of sustainability.

The potential measures for rethinking buildings and urban areas in these four typologies are:

- Mainly COVID-19 risk reduction measures: safe distance markers (lifts, public transport), disinfectant, hands-free door opening or possible replacements of materials with others (such as copper) that reduce virus residence time, unidirectional stairs. When the outbreak finishes, the potential of these measures will also end, although they may return in the event of other outbreaks, so they may be considered temporary or intermittent;

- Incremental measures: measures that will also bring benefits in terms of increasing resilience and whose potential could be adopted in the future, such as thermal sensors, new HVAC filters, touch-free digital and other IT solutions, unidirectional pedestrian paths; supplementary wastewater monitoring and treatment, more selective solid waste collection and treatment;

- Factorial measures: measures that not only contribute to risk reduction (also increasing resilience, together with an improved public health contribution), but also increase the search for sustainability in a broader perspective: minimalist design in buildings, avoiding carpets and rugs, flexible entrance areas, balconies, landscapes and the views from windows, increasing open access to sunlight, natural ventilation, new HVAC systems in non-residential buildings (linear flow extractions, increased humidity control, recovery) with potential mixed modes and a search for near-zero energy buildings. On an urban scale: increased green areas and nature-based solutions, local food production, renewable energy supply, local closed water cycle and the search for sustainable urban areas and buildings;

- Disruptive changes: besides the factorial measures, a disruptive option expands the level and the typologies of measures (not included in Figure 2). This will imply a change in lifestyle and the built environment in order to integrate a holistic approach with a structural reduction in resource consumptions and emissions (e.g., carbon neutral buildings), based on environmental sustainability, social inclusivity and a circular economy, of which sustainable urban areas and buildings are just one component.

These potential measures highlight different levels of contribution towards reducing risk, in which COVID-19 could leverage a sustainable built environment. They make it clear that health and sustainability cannot exist in different domains; sustainable buildings could be the bridge for increasing energy efficiency, ensuring good levels of comfort, air quality and health [87]. The lesson to be learned from this is that the built environment can offer support to the community in terms of greater resilience, and this lesson could be usefully incorporated into future planning [88].

Interconnected urban areas may have social inequalities and difficult living conditions. So, urbanisations in a global world could act as hubs for the transmission of diseases, challenging the planning process to reduce the weight of current and future infections [89] through the reorganisation of activities and the built environment.

These social inequalities mean that a fraction of the population may be more vulnerable to infectious diseases due to the precarious conditions in which they live. In the United States, for example, the mortality rate of COVID-19 has been higher among African-American populations, essentially due to the social inequalities that they experience in terms of employment and wages, and the built environments in which they live [90]. It is also important that strategic actions are taken to protect these most vulnerable populations, in order to counter the effects of the pandemic. Some of these actions involve improving housing conditions and built environments [91]. 
However, the benefits of each solution for sustainability can vary, depending on the reality of each country. For most of the population from poor regions or countries, guaranteeing the supply of water, energy and the collection of wastewater and solid waste will lead to a huge increase in public health and, if readily accessible, also to sustainability.

One of the consequences of the COVID-19 crisis is that it reduces available funds and potentially limits the search for sustainable development goals [92], although this could also be an opportunity for synergies that can create the conditions for maintaining the sustainability drive. Financing the construction of homes, especially in the form of affordable houses, will be a major challenge for governments and also one of the instruments that the State can use to improve welfare, as well as environmental performance and sustainable housing solutions [93].

Djalante et al. (2020) state that it is important to develop solutions and improve the response capacity to these events. Yet, at the same time, it is important to guarantee sustainable development in order to achieve the goals of the 2030 agenda [94].

One of the main challenges arising from the relationship between the COVID-19 pandemic and sustainable development is the question of mobility. The current pandemic has emphasised the importance of travelling in private vehicles to the detriment of public transport, since this can be considered a potential vector of viral transmission in the community [95]. Some of the potential solutions discussed in this paper offer an answer to this problem. They are all solutions that presuppose an investment in active mobility or the adoption of the teleworking regime. Other solutions, such as investing in touch-free digital technologies, with a lower energy consumption, can also offset the carbon emissions and energy consumption associated with this trend.

A disruptive change means a change in lifestyle, based, as Gills (2000) proposes, on a "deep restoration of the spiritual inner life of humanity", leading to a post-materialistic philosophy and a greater awareness of the need for maintaining essential ecological processes [96]. Forrester (2020) states that vulnerability must be answered through an ethics of care and kindness with flexible planning (or management) solutions, based on self-orientation, digital information and other decentralised approaches [97].

Finding answers to the broad-scale risks and challenges brought by climate change is essential. The search for mitigation and adaptation has been challenging the built environment to respond not only to today's needs, but also to the needs of future generations, something that is linked to the question of sustainability. We should be steering our economies towards neutral greenhouse gas emissions [98].

Keim (2008) states that climate change will increase the probability of extreme events, such as heatwaves, fires, extreme rainfall and floods and infectious diseases, among others. In turn, these phenomena can lead to public health crises, making it essential to adopt resilient solutions that will reduce human vulnerability to climate change and improve the ability to respond to emergencies [99].

Even systemic approaches can have limitations, in this case resulting from some of the aspects that have already been highlighted here, namely the definition of a scope that does not take into account the life cycle assessment of the solutions, their economic and social impact, people's behaviour and management activities or the supply chains and their maintenance during pandemic situations [100].

\section{Conclusions}

The built environment has a significant impact on health behaviours and disease transmission. The relationship is a complex one and could be viewed as public health moving from a sectoral silo-based approach centred on the health system and individual behaviour to an enlargement of other systems [22], such as the built environment.

The support that is provided in fighting pandemic infections will change, depending on whether more or fewer alterations are made to the built environment. The most relevant solutions not only resolve infections, but also enhance other functions, such as improvements in lifestyle (Roman Empire). In the great historical pandemics, some cases brought changes to urban areas (cholera), such as 
improvements in infrastructure and sanitation or even urban planning, while other cases led to changes in buildings (tuberculosis), with the emergence of innovative architectural aspects. However, other pandemics did not bring any structural changes to the built environment. Built environment changes are considered to be one of the most important factors in a broad approach.

The primary triggers for change are the perception of future risk (Black Death) and the possibility of the pandemic happening again. Other triggers include: scientific advances and greater knowledge about diseases (cholera, tuberculosis); difficulty in containing pandemics with only behavioural measures (Spanish flu); or combined solutions that improve public health and quality of life.

Social confinement creates a win-lose relationship between health (staying at home) and the economy (reduced economic activity, reduced income, bankruptcy), social effects (unemployment) and potential gains in some environmental dimensions (lower energy consumption, fewer air emissions).

This paper supports the rationale that a structural change in the built environment occurs when there is a convergence between the possible solution factors and the triggers for an essential change. It is, therefore, important to guarantee the capacity to find answers, making adjustments and evolving in various other dimensions besides health, such as, for example, in relation to economic, social and environmental aspects.

Built environment systems must provide answers to more than one function. In order to produce effective changes that can be adopted in a general fashion, solutions must solve multidimensional problems (relating to a number of social, environmental and economic aspects), making preparations for a reduction in the current profile of infectious risks (transmission of diseases) or other risks and their changes (mutations).

This analysis has identified the first level of measures that can be introduced into the built environment, mainly in order to reduce the risk of COVID-19 infection (safety distance markers (lifts, public transport), disinfectant, hands-free door opening or the possible replacement of materials with others, such as copper, that reduce the virus's residence time, unidirectional stairs). These measures could mainly mitigate the risk of transmission without bringing any other benefits in terms of sustainability (win-lose). Such temporary or intermittent measures would end with the outbreak.

There is a full set of measures that could also leverage sustainability aspects, ranging from incremental measures to factorial and disruptive measures. Incremental measures include: thermal sensors, new HVAC filters, touch-free digital and other IT solutions, unidirectional pedestrian pathways; supplementary wastewater monitoring and treatment measures, more selective solid waste collection and treatment; factorial measures, including minimalist design, avoiding the use of carpets and rugs, balconies, increased open access to sunlight, natural ventilation, new HVAC systems in non-residential buildings (linear flow extractions, increased humidity control, recovery) with potential mixed modes. Besides these, some disruptive changes can be considered, such as the search for near-zero energy buildings, and, on an urban scale, increased the provision of green and nature-based areas, local food production, local renewable energy supply and a local closed water cycle).

The pandemic outbreak creates an economic crisis and has major social implications for the world, opening up a discussion about which actions will lead to a more healthy and sustainable development trajectory [101]. This coronavirus pandemic will be an opportunity to adopt a wide-ranging response to the risk of infection, one in which climate change and other risks are also considered. This search for resilience must also ensure that evolution in technology and lifestyle leads to a more sustainable built environment with a positive balance between health and other social, economic and environmental aspects.

If there is a paradigm shift towards sustainable development, the benefits of any alterations can be greater and the proposed win-win approach will make it possible to identify potential solutions with a high level of sustainable buildings and urban areas (based on the supply of renewable energy, closed cycles for water and materials, resilience and socioeconomic factors). Structural leverage and disruptive change could happen if it is understood that this is an opportunity for a more profound social 
transformation to improve mitigation and make adaptations for climate change and environmental sustainability within the built environment. (e.g., carbon-neutral buildings).

This paper makes an innovative contribution to this subject by linking together the various pandemic challenges, providing a historical overview of the main global infectious diseases, and illustrating the changes that they have caused in built environments. It uses a systemic approach to identify the potential solutions that can be adopted in buildings and urban areas in order to reduce COVID-19 risks, linked to the dimensions of sustainability and resilience. It is hoped that the adoption of a broader strategy (moving beyond the silo-based approach of the health sector) will make it possible to leverage a sustainable built environment.

This study has made it possible to identify a full set of measures. Nevertheless, depending on the typology of buildings or areas-whether they are used for residential, commercial or other purposes-and whether the solutions take the form of new designs or refurbishment, such measures still require the guarantee of a flexible approach and much more research. Furthermore, designs that lead to an effective win-win solution in terms of resilience and sustainability are an essential area for further development and future research.

Author Contributions: Conceptualisation; M.D.P. Changes, Discussion and Conclusions, M.D.P.; Historical research and contributions to other parts, N.C.L. All authors have read and agreed to the published version of the manuscript.

Funding: This research received no external funding.

Acknowledgments: We are grateful to John Elliott for his suggestions regarding the use of English and to the anonymous reviewers for their questions and contributions.

Conflicts of Interest: The authors declare no conflict of interest.

\section{References}

1. Jones, D.S. History in a Crisis-Lessons for Covid-19. N. Engl. J. Med. 2020, 382, 1681-1683. [CrossRef] [PubMed]

2. World Health Organization (WHO). Q\&As on COVID-19 and Related Health Topics. Available online: https://www.who.int/emergencies/diseases/novel-coronavirus-2019/question-and-answers-hub (accessed on 26 May 2020).

3. Wilder-Smith, A.; Chiew, C.J.; Lee, V.J. Can we contain the COVID-19 outbreak with the same measures as for SARS? Lancet Infect. Dis. 2020, 20, e102-e107. [CrossRef]

4. World Health Organization (WHO). WHO Coronavirus Disease (COVID-19) Dashboard. Available online: https://covid19.who.int/ (accessed on 20 July 2020).

5. Ozili, P.K.; Arun, T. Spillover of COVID-19: Impact on the Global Economy. 2020. Available online: https://mpra.ub.uni-muenchen.de/99850/1/MPRA_paper_99850.pdf (accessed on 13 July 2020).

6. Nicola, M.; Alsafi, Z.; Sohrabi, C.; Kerwan, A.; Al-Jabir, A.; Iosifidis, C.; Agha, M.; Agha, R. The socio-economic implications of the coronavirus pandemic (COVID-19): A review. Int. J. Surg. 2020, 78, 185-193. [CrossRef] [PubMed]

7. Brooks, S.K.; Webster, R.K.; Smith, L.E.; Woodland, L.; Wessely, S.; Greenberg, N.; Rubin, G.J. The psychological impact of quarantine and how to reduce it: Rapid review of the evidence. Lancet 2020, 395, 912-920. [CrossRef]

8. Paital, B. Nurture to nature via COVID-19, a self-regenerating environmental strategy of environment in global context. Sci. Total Environ. 2020, 729, 139088. [CrossRef]

9. Klemeš, J.J.; Fan, Y.; Van Fan, Y.; Tan, R.R.; Jiang, P. Minimising the present and future plastic waste, energy and environmental footprints related to COVID-19. Renew. Sustain. Energy Rev. 2020, 127, 109883. [CrossRef]

10. Helm, D. The Environmental Impacts of the Coronavirus. Environ. Resour. Econ. 2020, 76, 21-38. [CrossRef]

11. Lin, W. Evental Infrastructure: Momentous Geographies of Technoscience Production. 2020. Available online: https://www.tandfonline.com/doi/full/10.1080/24694452.2020.1724766 (accessed on 13 July 2020).

12. Jacobsen, K.H. Will COVID-19 generate global preparedness? Lancet 2020, 395, 1013-1014. [CrossRef]

13. United Nations, Department of Economic and Social Affairs, Population Division (2019). World Urbanization Prospects. The 2018 Revision (ST/ESA/SER.A/420).; United Nations, Department of Economic and Social Affairs, Population Division (2019): New York, NY, USA, 2019. 
14. Reyes, R.; Ahn, R.; Thurber, K.; Burke, T.F. Urbanization and Infectious Diseases: General Principles, Historical Perspectives, and Contemporary Challenges. In Challenges in Infectious Diseases. Emerging Infectious Diseases of the 21st Century; Fong, I., Ed.; Springer: Berlin/Heidelberg, Germany, 2013; pp. 123-146. ISBN 978-1-4614-4496-1.

15. Honigsbaum, M. The Pandemic Century: One Hundred Years of Panic, Hysteria and Hubris; W. W. Norton \& Company: New York, NY, USA, 2020.

16. Web of Science (WoS). Available online: https://login.webofknowledge.com/ (accessed on 5 June 2020).

17. ScienceDirect (SD). Available online: https://www.sciencedirect.com/ (accessed on 5 June 2020).

18. Dietz, L.; Horve, P.F.; Coil, D.A.; Fretz, M.; Eisen, J.A.; Van Den Wymelenberg, K. 2019 Novel Coronavirus (COVID-19) Pandemic: Built Environment Considerations To Reduce Transmission. MSystems 2020, 5, e00245-20. [CrossRef]

19. Eykelbosh, A. COVID-19 Precautions for Multi-Unit Residential Buildings. 2020. Available online: https://ncceh.ca/sites/default/files/COVID-19\%20Precautions\%20for\%20Multiunit\%20Residential\% 20Buildings\%20-\%20March\%2031\%202020.pdf (accessed on 13 July 2020).

20. Cirrincione, L.; Plescia, F.; Ledda, C.; Rapisarda, V.; Martorana, D.; Moldovan, R.; Theodoridou, K.; Cannizzaro, E. COVID-19 Pandemic: Prevention and Protection Measures to be Adopted at the Workplace. Sustainability 2020, 12, 3603. [CrossRef]

21. Leal Filho, W.; Brandli, L.L.; Lange Salvia, A.; Rayman-Bacchus, L.; Platje, J. COVID-19 and the UN Sustainable Development Goals: Threat to Solidarity or an Opportunity? Sustainability 2020, 12, 5343. [CrossRef]

22. Frank, L.D.; Iroz-Elardo, N.; MacLeod, K.E.; Hong, A. Pathways from built environment to health: A conceptual framework linking behavior and exposure-based impacts. J. Transp. Health 2019, 12, 319-335. [CrossRef]

23. Jordan, D.P. Transforming Paris: The Life and Labors of Baron Haussman. University of Chicago Press: Chicago, IL, USA, 1995.

24. Kirkland, S. Paris Reborn: Napoléon III, Baron Haussmann, and the Quest to Build a Modern City. St. Martin's Press: New York, NY, USA, 2014.

25. Cazzolla Gatti, R. Coronavirus outbreak is a symptom of Gaia's sickness. Ecol. Modell. 2020, 426, 109075. [CrossRef] [PubMed]

26. Sofo, A.; Sofo, A. Converting Home Spaces Into Food Gardens At the Time of Covid-19 Quarantine: All the Benefits of Plants in This Difficult and Unprecedented Period. 2020. Available online: https: //www.ncbi.nlm.nih.gov/pmc/articles/PMC7171439/ (accessed on 13 July 2020).

27. Cohen, M.J. Does the COVID-19 outbreak mark the onset of a sustainable consumption transition? Sustain. Sci. Pract. Policy 2020, 16, 1-3. [CrossRef]

28. Acuto, M. COVID-19: Lessons for an Urban(izing) World. One Earth 2020, 2, 317-319. [CrossRef]

29. Belfiglio, V.J. Control of epidemics in the Roman army: 27 B.C.-A.D. 476. Int. J. Community Med. Public Health 2017, 4, 1387. [CrossRef]

30. Bruun, C. The Water Supply of Ancient Rome: A Study of Roman Imperial Administration. Societas scientiarum Fennica: Helsinki, Finland, 1991.

31. Follet, K. World Without End: A Novel (Kingsbridge); Penguin Books: London, UK, 2010.

32. Cohn, S.K. Epidemiology of the Black Death and Successive Waves of Plague. Med. Hist. 2008, 52, 74-100. [CrossRef]

33. Bramanti, B.; Stenseth, N.C.; Walløe, L.; Xu, L. Plague: A Disease Which Changed the Path of Human Civilization. 2016. Available online: https://www.researchgate.net/publication/308959724_Plague_A_ Disease_Which_Changed_the_Path_of_Human_Civilization (accessed on 13 July 2020).

34. Sloan, A.W. Medical and social aspects of the great plague of London in 1665. S. Afr. Med. J. 1973, 47, $270-276$.

35. Lilley, K.D. Urban planning after the Black Death: Townscape transformation in later medieval England (1350-1530). Urban History 2015, 42, 22-42. [CrossRef]

36. Vereycken, K. Leonardo da Vinci Imagines The First Modern City. Exec. Intell. Rev. 2010, 37, 53-55.

37. Glass, R.I.; Black, R.E. The epidemiology of cholera. In Cholera; Braua, D., Greenough, W.B., Eds.; Springer: Boston, MA, USA; ISBN 9781475796889.

38. Lippi, D.; Gotuzzo, E.; Caini, S. Cholera. Microbiol. Spectr. 2016, 4. [CrossRef] 
39. Tulodziecki, D. A case study in explanatory power: John Snow's conclusions about the pathology and transmission of cholera. Stud. Hist. Philos. Sci. Part C Stud. Hist. Philos. Biol. Biomed. Sci. 2011, 42, 306-316. [CrossRef] [PubMed]

40. Szczygiel, B.; Hewitt, R. Nineteenth-Century Medical Landscapes: John H. Rauch, Frederick Law Olmsted, and the Search for Salubrity. Bull. Hist. Med. 2000, 74, 708-734. [CrossRef] [PubMed]

41. Ball, L. Cholera and the Pump on Broad Street: The Life and Legacy of John Snow. Hist. Teacher 2009, 43, 105-119.

42. Gandy, M. The Paris Sewers and the Rationalization of Urban Space. Trans. Inst. Br. Geogr. 1999, $24,23-44$. [CrossRef]

43. Campbell, M. What tuberculosis did for modernism: The influence of a curative environment on modernist design and architecture. Med. Hist. 2005, 49, 463-488. [CrossRef]

44. Abdullah Ali, F. The Influence of Le Corbusier On the emergence of the Aesthetic Values in the Modern Architecture of Cyprus. J. Contemp. Urban Aff. 2018, 2, 1-12. [CrossRef]

45. Martini, M.; Gazzaniga, V.; Behzadifar, M.; Bragazzi, N.L.; Barberis, I. The history of tuberculosis: The social role of sanatoria for the treatment of tuberculosis in Italy between the end of the 19 th century and the middle of the 20 th. J. Prev. Med. Hyg. 2018, 59, E323-E327. [CrossRef]

46. Adams, A.; Schwartzman, K.; Theodore, D. Collapse and expand: Architecture and tuberculosis therapy in Montreal, 1909, 1933, 1954. Technol. Cult. 2008, 49, 908-942. [CrossRef]

47. Mann, T. Der Zauberberg; Fischer, S.: Berlin, Germany, 1924.

48. Kamradt-Scott, A. Changing perceptions of pandemic influenza and public health responses. Am. J. Public Health 2012, 102, 90-98. [CrossRef]

49. Rosner, D. Lessons Learned from the 1918-1919 Influenza Pandemic in Minneapolis and St. Paul, Minnesota. Public Health Rep. 2007, 122, 803-810. [CrossRef]

50. Baldwin, A.N. Sars and the built environment in Hong Kong. Proc. Inst. Civ. Eng. Munic. Eng. 2006, 159, 37-42. [CrossRef]

51. Oxley, D. 'The seat of death and terror': Urbanization, stunting, and smallpox. Econ. Hist. Rev. 2003, 56, 623-656. [CrossRef]

52. Connolly, C.; Keil, R.; Ali, S.H. Extended urbanisation and the spatialities of infectious disease: Demographic change, infrastructure and governance. 2020. Available online: https://journals.sagepub.com/doi/full/10. 1177/0042098020910873 (accessed on 13 July 2020).

53. Barberis, I.; Bragazzi, N.L.; Galluzzo, L.; Martini, M. The history of tuberculosis: From the first historical records to the isolation of Koch's bacillus. J. Prev. Med. Hyg. 2017, 58, E9-E12. [CrossRef]

54. The New York Times Style Magazine. In Search of Lost Time in Europe's Sanatoriums. Available online: https://www.nytimes.com/2018/02/18/t-magazine/sanatorium-europe-history.html (accessed on 14 July 2020).

55. Dezeen Du Besset-Lyon. Transforms Former Sanatorium into Clermont-Ferrand School of Architecture. Available online: https://www.dezeen.com/2015/11/11/clermont-ferrand-school-of-architecture-du-bessetlyon-architectes-urbanistes-former-sanatorium-france/ (accessed on 14 July 2020).

56. Neiderud, C.J. How urbanization affects the epidemiology of emerging infectious diseases. Infect. Ecol. Epidemiol. 2015, 5, 27060. [CrossRef]

57. Brizuela, N.G.; Garcia-Chan, N.; Pulido, H.G.; Chowell, G. Understanding the role of urban design in disease spreading. 2020. Available online: https://www.biorxiv.org/content/10.1101/766667v2.full (accessed on 13 July 2020).

58. European Comission (EC). COVID-19: Guidelines on the Progressive Restoration of Transport Services and Connectivity. European Commission: Brussels, Belgium, 2020.

59. World Health Organization (WHO). Strengthening Preparedness for COVID-19 in Cities and Urban Settings: Interim Guidance forLocal Authorities; World Health Organization: Geneva, Switzerland, 2020; Licence: CC BY-NC-SA 3.0 IGO.

60. Weston Williamson + Partners Weston Williamson + Partners Envisions Social-Distancing Office. Available online: https://www.dezeen.com/2020/05/14/weston-williamson-social-distancing-office/ (accessed on 29 May 2020).

61. Semple, S.; Cherrie, J.W. Covid-19: Protecting Worker Health. Ann. Work Expo. Health 2020, 64, 461-464. [CrossRef] 
62. Larsson, N. Pandemics and the Built Environment. 2020. Available online: https://www.researchgate.net/ publication/342376251_Pandemics_and_the_Built_Environment_22June20 (accessed on 13 July 2020).

63. van den Bosch, M.; Ode Sang, Å. Urban natural environments as nature-based solutions for improved public health-A systematic review of reviews. Environ. Res. 2017, 158, 373-384. [CrossRef]

64. Kurnitski, J.; Boerstra, A.; Franchimon, F.; Mazzarella, L.; Hogeling, J.; Hovorka, F.; Seppänen, O. REHVA COVID-19 guidance document. 2020. Available online: https://www.rehva.eu/fileadmin/user_upload/ REHVA_COVID-19_guidance_document_ver2_20200403_1.pdf (accessed on 13 July 2020).

65. Marr, L.C.; Tang, J.W.; Van Mullekom, J.; Lakdawala, S.S. Mechanistic insights into the effect of humidity on airborne influenza virus survival, transmission and incidence. J. R. Soc. Interface 2019, 16, 20180298. [CrossRef]

66. Moriyama, M.; Hugentobler, W.J.; Iwasaki, A. Seasonality of Respiratory Viral Infections. Annu. Rev. Virol. 2020, 7, 1-19. [CrossRef]

67. van Doremalen, N.; Bushmaker, T.; Morris, D.H.; Holbrook, M.G.; Gamble, A.; Williamson, B.N.; Tamin, A.; Harcourt, J.L.; Thornburg, N.J.; Gerber, S.I.; et al. Aerosol and Surface Stability of SARS-CoV-2 as Compared with SARS-CoV-1. N. Engl. J. Med. 2020. [CrossRef]

68. Kampf, G.; Todt, D.; Pfaender, S.; Steinmann, E. Persistence of coronaviruses on inanimate surfaces and their inactivation with biocidal agents. J. Hosp. Infect. 2020, 104, 246-251. [CrossRef] [PubMed]

69. Schuit, M.; Gardner, S.; Wood, S.; Bower, K.; Williams, G.; Freeburger, D.; Dabisch, P. The Influence of Simulated Sunlight on the Inactivation of Influenza Virus in Aerosols. J. Infect. Dis. 2019, 221, 372-378. [CrossRef] [PubMed]

70. Nghiem, L.D.; Morgan, B.; Donner, E.; Short, M.D. The COVID-19 pandemic: Considerations for the waste and wastewater services sector. Case Stud. Chem. Environ. Eng. 2020, 1, 100006. [CrossRef]

71. World Health Organization (WHO). Q\&A on Coronaviruses (COVID-19). Available online: https://www.who.int/emergencies/diseases/novel-coronavirus-2019/question-and-answers-hub/q-adetail/q-a-coronaviruses (accessed on 11 May 2020).

72. Ko, W.H.; Schiavon, S.; Zhang, H.; Graham, L.T.; Brager, G.; Mauss, I.; Lin, Y.-W. The impact of a view from a window on thermal comfort, emotion, and cognitive performance. Build. Environ. 2020, 175, 106779. [CrossRef]

73. Preiss, S.; Kramer, A. Foot-operated door opener to eliminate the door handle as a source of contamination. GMS Krankenhhyg. Interdiszip. 2011, 6, 10. [CrossRef]

74. Chen, C.; Zhang, X.-J.; Wang, Y.; Zhu, L.-X.; Liu, J. Waste water disinfection during SARS epidemic for microbiological and toxicological control. Biomed. Environ. Sci. 2006, 19, 173-178.

75. Tronville, P.; Rivers, R.D. International standards: Filters for buildings and gas turbines. Filtr. Sep. 2005, 42, 39-43. [CrossRef]

76. Becher, R.; Øvrevik, J.; Schwarze, P.E.; Nilsen, S.; Hongslo, J.K.; Bakke, J.V. Do carpets impair indoor air quality and cause adverse health outcomes: A review. Int. J. Environ. Res. Public Health 2018, 15, 184. [CrossRef]

77. Canadian Psychological Association. Traumatic Stress Section Executive Managing COVID-19 Anxiety-Resources. Available online: https://cpa.ca/resources-for-managing-covid-19-anxiety-cpatraumatic-stress-section/ (accessed on 13 July 2020).

78. Martineau, A.R.; Jolliffe, D.A.; Hooper, R.L.; Greenberg, L.; Aloia, J.F.; Bergman, P.; Dubnov-Raz, G.; Esposito, S.; Ganmaa, D.; Ginde, A.A.; et al. Vitamin D supplementation to prevent acute respiratory tract infections: Systematic review and meta-analysis of individual participant data. 2017. Available online: https://www.bmj.com/content/356/bmj.i6583 (accessed on 13 July 2020).

79. Abraham, A.; Sommerhalder, K.; Abel, T. Landscape and well-being: A scoping study on the health-promoting impact of outdoor environments. Int. J. Public Health 2009, 55, 59-69. [CrossRef]

80. Pinter-Wollman, N.; Jelic, A.; Wells, N.M. The impact of the built environment on health behaviours and disease transmission in social systems. Philos. Trans. R. Soc. B Biol. Sci. 2018, 373, 20170245. [CrossRef]

81. Saez, M.; Tobias, A.; Varga, D.; Barceló, M.A. Effectiveness of the measures to flatten the epidemic curve of COVID-19. The case of Spain. Sci. Total Environ. 2020, 727, 138761. [CrossRef] [PubMed]

82. Yeom, S.; Kim, H.; Hong, T.; Park, H.S.; Lee, D.-E. An integrated psychological score for occupants based on their perception and emotional response according to the windows' outdoor view size. Build. Environ. 2020, 180, 107019. [CrossRef] 
83. Writing Urban Places COST Socially Distanced-Windows Looking (and Listening) to Nature Where I Resided. Available online: https://writingurbanplaces.eu/wup-news/socially-distanced-windows-lookingand-listening-to-nature-where-i-resided/ (accessed on 14 July 2020).

84. Alaloul, W.S.; Liew, M.S.; Zawawi, N.A.W.A.; Kennedy, I.B. Industrial Revolution 4.0 in the construction industry: Challenges and opportunities for stakeholders. Ain Shams Eng. J. 2020, 11, 225-230. [CrossRef]

85. Brattig, N.W.; Tanner, M.; Bergquist, R.; Utzinger, J. Impact of environmental changes on infectious diseases: Key findings from an international conference in Trieste, Italy in May 2017. 2017. Available online: https://www.sciencedirect.com/science/article/abs/pii/S0001706X19312252 (accessed on 13 July 2020).

86. Mears, M.; Brindley, P.; Jorgensen, A.; Ersoy, E.; Maheswaran, R. Greenspace spatial characteristics and human health in an urban environment: An epidemiological study using landscape metrics in Sheffield, UK. Ecol. Indic. 2019, 106, 105464. [CrossRef]

87. Allen, J.G.; Macomber, J.D. Healthy Buildings: How Indoor Spaces Drive Performance and Productivity; Harvard University Press: Cambridge, MA, USA, 2020; ISBN 9780674237971.

88. Keenan, J.M. COVID, resilience, and the built environment. Environ. Syst. Decis. 2020, 40, 216-221. [CrossRef] [PubMed]

89. Alirol, E.; Getaz, L.; Stoll, B.; Chappuis, F.; Loutan, L. Urbanisation and infectious diseases in a globalised world. Lancet. Infect. Dis. 2011, 11, 131-141. [CrossRef]

90. Braithwaite, R.; Warren, R. The African American Petri Dish. 2020. Available online: https://preprint.press. jhu.edu/jhcpu/sites/default/files/02_warren.pdf1762847 (accessed on 13 July 2020).

91. Schulz, A.J.; Mehdipanah, R.; Chatters, L.M.; Reyes, A.G.; Neblett, E.W.; Israel, B.A. Moving Health Education and Behavior Upstream: Lessons From COVID-19 for Addressing Structural Drivers of Health Inequities. Health Educ. Behav. 2020, 47, 519-524. [CrossRef]

92. Sherr, L.; Cluver, L.; Desmond, C.; Toska, E.; Aber, L.; Dhaliwal, M.; Webb, D.; Dugbazah, J. A new vehicle to accelerate the UN Sustainable Development Goals. Lancet Glob. Health 2020, 8, e637-e638. [CrossRef]

93. Wijburg, G. The de-financialization of housing: Towards a research agenda. 2019. Available online: https://www.tandfonline.com/doi/full/10.1080/02673037.2020.1762847 (accessed on 13 July 2020).

94. Djalante, R.; Shaw, R.; DeWit, A. Building resilience against biological hazards and pandemics: COVID-19 and its implications for the Sendai Framework. Prog. Disaster Sci. 2020, 6, 100080. [CrossRef]

95. Kanda, W.; Kivimaa, P. What opportunities could the COVID-19 outbreak offer for sustainability transitions research on electricity and mobility? Energy Res. Soc. Sci. 2020, 68, 101666. [CrossRef]

96. Gills, B. Deep Restoration: From The Great Implosion to The Great Awakening. Globalizations 2020, 17, 577-579. [CrossRef]

97. Forester, J. Kindness, Planners' Response to Vulnerability, and an Ethics of Care in the Time of Covid-19. Plan. Theory Pract. 2020, 21, 185-188. [CrossRef]

98. Hepburn, C.; O'Callaghan, B.; Stern, N.; Stiglitz, J.; Zenghelis, D. Will COVID-19 fiscal recovery packages accelerate or retard progress on climate change? Oxford Rev. Econ. Policy 2020, 36, 1-48. [CrossRef]

99. Keim, M.E. Building Human Resilience: The Role of Public Health Preparedness and Response As an Adaptation to Climate Change. Am. J. Prev. Med. 2008, 35, 508-516. [CrossRef]

100. Queiroz, M.M.; Ivanov, D.; Dolgui, A.; Fosso Wamba, S. Impacts of epidemic outbreaks on supply chains: Mapping a research agenda amid the COVID-19 pandemic through a structured literature review. 2020. Available online: https://link.springer.com/article/10.1007/s10479-020-03685-7 (accessed on 13 July 2020).

101. Lucchese, M.; Pianta, M. The Coming Coronavirus Crisis: What Can We Learn? Intereconomics 2020, 55, 98-104. [CrossRef]

(C) 2020 by the authors. Licensee MDPI, Basel, Switzerland. This article is an open access article distributed under the terms and conditions of the Creative Commons Attribution (CC BY) license (http://creativecommons.org/licenses/by/4.0/). 